\begin{tabular}{|c|l|}
\hline Title & From engineer to taxi driver? Language proficiency and the occupational skills of immigrants \\
\hline Author(s) & Imai, Susumu; Stacey, Derek; W arman, Casey \\
\hline Citation & $\begin{array}{l}\text { Canadian Journal of Economics,Revue canadienne d'économique, 52(3), 914-953 } \\
\text { https://doi.org/10.1111/caje.12396 }\end{array}$ \\
\hline Issue Date & 2019-08_27 \\
\hline Doc URL & http://hdl.handle.net/2115/82563 \\
\hline Type & article(author version) \\
\hline File Information & caje_12396_Rev2.pdf \\
\hline
\end{tabular}

Instructions for use 


\section{From engineer to taxi driver? Language proficiency and the occupational skills of immigrants}

Susumu Imai

Faculty of Economics and Business, Hokkaido University

Derek Stacey

Department of Economics, Ryerson University

Casey Warman

Department of Economics, Dalhousie University; NBER

Abstract. We examine the ability of immigrants to transfer the occupational human capital they acquired prior to immigration. We first augment a model of occupational choice to study the implications of language proficiency on the cross-border transferability of occupational human capital. We then explore the empirical predictions using information about the skill requirements from O*NET and a unique dataset that includes both the last source country occupation and the first four years of occupations in Canada. We supplement the analysis using Census estimates for the same cohort with source country occupational skill requirements predicted using detailed human capital related information such as field of study. We find that male immigrants to Canada were employed in source country occupations that typically require high levels of cognitive skills, but rely less intently on manual skills. Following immigration, they find initial employment in occupations that require the opposite. Consistent with the hypothesized

Corresponding author: Casey Warman, warmanc@dal.ca

Helpful comments were received from Christopher Worswick, Urvashi Dhawan-Biswal, Michael Baker, two anonymous referees and participants at the Canadian Economics Association Conference in Quebec City (2010), the Conference on the Economics of Immigration in Ottawa (2010), the Institute for Research on Public Policy (IRPP) Conference on Canada's Immigration Policy (2010), the John Deutsch Institute Conference on Income, Inequality, and Immigration (2011) as well as the Conference on Ageing and Demographics in Bouctouche New Brunswick (2012) and seminars at City University London, Dalhousie University, Hokkaido University, Queen's University, Ryerson University, Université du Québec à Montréal and University of Manitoba. The analysis presented in this paper was conducted mainly at the Atlantic Research Data Centre, which is part of the Canadian Research Data Centre Network (CRDCN). The services and activities provided by the Atlantic Research Data Centre are made possible by the financial or in-kind support of the SSHRC, the CIHR, the CFI, Statistics Canada and Dalhousie University. The views expressed in this paper do not necessarily represent those of the CRDCN or its partners. We are also grateful to RDC analyst Heather Hobson for her assistance and to Lachlan MacLeod. Any errors are our own.

Canadian Journal of Economics / Revue canadienne d'économique 2019 52(3)

August 2019. Printed in Canada / Août 2019. Imprimé au Canada

ISSN: 0008-4085 / 19 / pp. 914-953 / (c) Canadian Economics Association 
asymmetric role of language in the transferability of previously acquired cognitive and manual skills, these discrepancies are larger among immigrants with limited language fluency.

Résumé. D'ingénieur à chauffeur de taxi? Les aptitudes linguistiques et les compétences professionnelles des immigrants. Dans cet article, nous avons étudié la capacité des immigrants à transférer leur capital humain professionnel développé avant leur immigration. Tout d'abord, nous avons élaboré un modèle augmenté de choix professionnels afin d'étudier l'incidence des aptitudes linguistiques sur la transférabilité transfrontalière du capital humain professionnel. Nous avons ensuite exploré les prévisions empiriques en utilisant les données du système $O^{*}$ NET ainsi qu'un ensemble de données uniques présentant à la fois le dernier poste occupé dans le pays de départ et les quatre premières années en emploi au Canada. Nous avons complété cette analyse en utilisant les estimations du recensement correspondant à cette même population afin d'évaluer les qualifications professionnelles requises dans le pays d'origine en tenant compte de diverses informations détaillées relatives au capital humain, notamment le domaine d'étude. Nous avons découvert que dans leur pays d'origine, les immigrants de sexe masculin au Canada étaient employés dans des domaines professionnels nécessitant habituellement des compétences cognitives de haut niveau et ne reposant pas sur des compétences manuelles. Suite à leur immigration, ils trouvent leur premier emploi dans des domaines professionnels nécessitant des compétences manuelles ne reposant pas sur des compétences cognitives. Conformément à I'hypothèse du rôle asymétrique de la langue dans la transférabilité des compétences manuelles et cognitives acquises avant l'immigration, ces différences sont plus importantes parmi les immigrants aux compétences linguistiques limitées.

JEL classification: J24, J31, J61, J62, J71, J80

\section{Introduction}

حhe potential benefits to an immigrant-receiving country like Canada from attracting high skilled immigrants can be realized only if the immigrants admitted are successful in finding employment in jobs that require the human capital they bring with them. Severe instances of human capital mismatch, such as the example referenced in the title of the paper, have been well publicized in Canada $^{1}$ and call into question the success of the Canadian immigration system. Due to difficulties in defining and assessing occupational mismatch, however, existing research focuses on either education or occupation groupings (e.g., based on skill levels or skill types). The education approach leads one to classify a mismatch in terms of over-education, defined as excess foreign acquired education relative to the prevailing educational requirements of their host country occupation. ${ }^{2}$ In contrast, by grouping specific occupations into broader categories, one can define mismatch in terms of the non-equivalence of the pre- and post-

1 Dharssi (2016) and Chapin (2012) are among the numerous popular press articles on this issue.

2 For example, Chiswick and Miller (2008, 2009). 
immigration occupation groups. ${ }^{3}$ In this paper, we offer a different perspective for assessing the meaning and severity of occupational mismatch by examining the transferability of immigrants' human capital in terms of the prevailing cognitive and manual skill requirements of their occupations. We present theory and descriptive evidence on the mismatch of occupational skills-based human capital. Our analyses suggest that dominant language proficiency is closely linked to the efficient transfer of occupational human capital.

In the occupational mobility and immigration literatures, researchers often classify the numerous occupations into a few broad groups. A common classification system is the blue/white collar dichotomy based on skill requirements (i.e., primarily manual versus occupations relying more intently on cognitive skills) (Green 1999, Cohen-Goldner and Eckstein 2010). This approach potentially underutilizes important occupational information. ${ }^{4}$ One solution involves more finely partitioned classification systems. Warman et al. (2015) use 10, 25, 47 and 139 occupation groupings to study the ability of immigrants to find employment in an occupation belonging to the same category as (and hence directly related to) the occupation they held prior to immigrating. The evidence shows that occupational matching is an important determinant of immigrants' earnings, as well as the returns to years of foreign schooling. However, the incidence of occupational mismatch grows as the classification system becomes more finely defined. This is an undesirable feature, since immigrants who are unable to secure employment in the same occupation may be able to transfer human capital to a new job if it is similar in terms of the required skills.

Poletaev and Robinson (2008) find that occupational skills, rather than industries or occupations, are the most important source of human capital specificity in the determination of earnings for displaced workers. ${ }^{5}$ Applying the notion of skill-specific human capital to the study of immigrant outcomes leads to a new set of questions: How drastic is the general shift in skill requirements encountered by immigrants? Does the transferability of certain skills rely heavily on other factors, such as language fluency or credential recognition?

3 For example, Green (1999), Cohen-Goldner and Eckstein (2010), Warman et al. (2015).

4 Recent papers in occupational choice literature such as Ingram and Neumann (2006), Bacolod and Blum (2010), Poletaev and Robinson (2008), Yamaguchi (2012) and others demonstrate that there are important differences in the skill requirements of occupations even within the broad occupational categories.

5 Recent papers investigate the issue of human capital specificity. Neal (1995) and Parent (2000) examine the importance of industry-specific human capital, while Kambourov and Manovskii (2009) show that occupational tenure is an important determinant of wages among working age employed males in the US. See Robinson (2018) for a comparison of voluntary and involuntary occupation switchers. 
We explore these issues using a unique dataset that provides information not only on the labour market experiences of immigrants during the first four years after immigrating to Canada but also on the last occupation held in the source country prior to immigrating. We follow Ingram and Neumann (2006), Bacolod and Blum (2010), Poletaev and Robinson (2008), Yamaguchi (2012) and others and derive a small set of fundamental skill requirements for each job from the detailed information in an occupation database. We construct a vector (portfolio) of skill measures that summarizes the skill requirements for each occupation listed in the Occupational Information Network (O*NET). The vector consists of five variables; two of them correspond to cognitive skills (analytical and interpersonal skills) and the remaining three to manual skills (fine motor skills, visual skills and physical strength). By matching the source and host country occupations recorded in the Longitudinal Survey of Immigrants to Canada (LSIC) with those in the O*NET table and their corresponding vectors of skill requirements, we compare the ascribed skil1 requirements for all pre- and post-immigration jobs for male immigrants and calculate the implied gain or loss in required skills that resulted from immigration. ${ }^{6}$

We find that immigrants worked in source country occupations prior to migrating to Canada that generally require skill portfolios with higher levels of interpersonal and analytical skills relative to the occupations of the Canadian population, but lower motor skills, physical strength and visual skill requirements. This could be an indication of the success of Canadian immigration policy geared towards attracting immigrants with high cognitive skills applicable to high technology, high knowledge economies. In the short term following migration to Canada, however, they work in occupations that not only require analytical skills and interpersonal skills that are lower than those ascribed to their source country occupations but also are more demanding in terms of motor skills, physical strength and visual skills. In other words, recent immigrants are working in jobs that do not utilize the cognitive skills that are sought after by immigrant receiving countries, but instead find jobs that require manual skills with which, given their source country work experience, they might be under-equipped.

Is it naive for an immigrant with foreign work experience as an engineer, for example, to expect employment opportunities related to engineering? Such expectations do not seem unreasonable, especially among immigrants selected through a point system designed to bring in people with the skills and

6 We focus on male immigrants since, in addition to gender differences in labour market constraints that are beyond the scope of this paper, a large percentage of females had not worked prior to immigrating. While only $3 \%$ of male immigrants had not worked prior to immigrating, $20 \%$ of females do not report a source country occupation. In addition, a much larger percentage of males are assessed directly under the Canadian point system and are therefore admitted based on human capital considerations. 
qualifications required to integrate into the Canadian labour market. Given that two-thirds of our sample were directly assessed via the Canadian point system and admitted based on human capital considerations, the skill gaps that we document are cause for concern. An important caveat, however, is that while they may reflect the information assessed by the point system and limited success in transferring source country occupational human capital, these skill patterns potentially mismeasure the true skill gaps if the O*NET information does not accurately describe the skill content of occupations in all source countries.

To minimize the measurement error introduced by inappropriately assigning O*NET-derived skill requirements to occupations in other countries, we emphasize the set of results for immigrants from OECD countries. This is premised on OECD countries being similar to the US in terms of production technologies and hence occupational skill requirements. For some non-OECD countries with economies that are less technology and knowledge oriented, our methodology potentially systematically overestimates occupational cognitive skill requirements and underestimates manual skill requirements. When we examine the full sample of immigrants, it is not surprising then that the imputed skill gaps are more severe. In this sense, our skills-based measures of source country human capital do not overcome the potential measurement issues resulting from quality differences and comparability between host and source countries that are all too familiar in the over-education literature. ${ }^{7}$ Notwithstanding seemingly legitimate concerns over measurement error, we argue that the qualitative pattern documented for immigrants from OECD countries calls for further analysis.

An important consideration is the role of dominant language proficiency in the transferability of occupational skills to a new labour market. In particular, we argue that the transfer of cognitive skills relies more heavily on language proficiency than the transfer of manual skills. Cognitive tasks tend to be carried out in environments that also require communication and interactions with others, while manual tasks can be performed in isolation or with minimum coordination and communication with clients and colleagues. We develop a simple occupational choice model with cognitive and manual skill endowments/requirements to derive the implications of asymmetry in the role of language in the transferability of skills. In keeping with the theoretical model, we find that the initial mismatch in skill requirements is markedly more severe among less fluent immigrants. Moreover, we document evidence of convergence for non-native English/French speakers only, which is consistent

7 See, for example, Green et al. (2007), Chiswick and Miller (2008), Lindley (2009) and Nielsen (2011). The strands of the immigration literature examining earning differentials and educational attainment also share the tradition of treating educational outcomes as equivalent across countries (e.g., Chiswick and DebBurman 2004, Ferrer and Riddell 2008, Green and Worswick 2012 and Kaushal et al. 2016). 
with the impact of language since dominant language proficiency presumably improves after migration. Indeed, we find that reported improvement in language ability is associated with an expedited decline in occupational skill gaps.

We carry out a series of robustness exercises to address issues of measurement error that are inherent in cross-country comparisons of human capital. We again examine the occupational skill transferability of immigrants from OECD countries separately by language group. To accomplish this, we analyze the larger sample of immigrants in the 2006 Census, which necessitates predicting source country occupational skill requirements using human capital related information such as field of study. ${ }^{8}$ The results are reassuring, however; it remains altogether possible that countries similar to Canada in terms of labour markets and human capital endowments also tend to have similar linguistic backgrounds. Accordingly, we report skill gaps for the LSIC sample of immigrants from a single non-OECD source country ${ }^{9}$ by language group. We find the resulting exploratory analysis of occupational skill transferability and language proficiency both interesting and informative because the patterns that emerge for the full LSIC sample, the single source country LSIC subsample and the Census OECD sample are all qualitatively identical. Using the full LSIC and Census samples and OECD Census subsample, we next explore the robustness of the relationship between skill gaps and language fluency with regression analysis. Importantly, we control for source country with a set of dummy variables in case English/French language fluency variables are picking up variation in the overall quality of source country human capital. ${ }^{10}$ We conclude that the qualitative features of our main findings are robust across all specifications and sample selection criteria considered; specifically, we document cognitive skill gaps that decline with language ability.

8 The mean Canadian and (predicted) source country occupational skill requirements for the Census sample of immigrants from OECD countries line up almost exactly with the corresponding LSIC estimates. The same is true when considering the full sample of countries.

9 We choose the source country with the largest sample of LSIC respondents, namely China.

10 We obtain similar results using GDP (specifically, the difference between source country GDP per capita and Canada's GDP per capita) as a proxy for economic and labour market similarity to Canada. Note that a large body of research has relied on GDP and other aggregate measures of economic performance to capture source country differences in technology and human capital. For example, Coulombe et al. (2014) condition on source country GDP per capita to capture variation in the quality of schooling and work experience across source countries. They also point out that GDP per capita has a strong positive correlation with cognitive test scores. Li and Sweetman (2014) include results from international test scores as well as GDP per capita as explanatory variables in a study of the returns to schooling among immigrants to Canada. 
The large literature examining the economic integration of immigrants has focused on a long list of specific issues: little or no returns to foreign attained schooling and foreign work experience (Schaafsma and Sweetman 2001, Warman 2010); the benefits of dominant language proficiency (Chiswick and Miller 1995, 2012, 2013; Ferrer et al. 2006; Skuterud 2011; Adserà and Ferrer 2015); ${ }^{11}$ the impact of job-education mismatch on earnings (Chiswick and Miller 2008, 2009; Dean 2010; Sharaf 2013); discrimination (Oreopoulos 2011, Dechief and Oreopoulos 2012); the consequences of a changing source country composition (Aydemir and Skuterud 2005); and the declining outcomes of all new labour market entrants (Green and Worswick 2012). These studies share the broad view that immigrants have difficulty bringing their human capital to the host country labour market. Some studies view human capital as educational attainment, others consider foreign work experience and still others focus on region-specific human capital such as language skills. In this regard, our analysis complements these strands of the literature, but differs in its adoption of the skills-based view of human capital. ${ }^{12}$ Occupational skills, when combined with measures of language proficiency, provide a novel perspective from which to characterize and assess an immigrant's current human capital. ${ }^{13}$

In the next section, we present the model that applies an occupational skills-based view of human capital to the analysis of immigrant labour market outcomes. In section 3, we describe the data and outline our empirical methodology. In section 4 we report our empirical results, and in section 5 we conclude.

11 Adserà and Ferrer (2015) estimate returns to host country skills (the same skill measures constructed in this paper) and linguistic proximity between source and host country languages among male immigrants to Canada.

12 Several other recent papers in the immigration literature adopt a skill- or task-based approach to human capital; Peri and Sparber (2009) consider task specialization among immigrants and natives in the US; Warman and Worswick (2015) examine the relationships between language ability, technological change and the worsening economic outcomes of immigrants in Canada; Schuetze and Wood (2014) examine of the role social networks in the occupational choices of immigrants to Canada; and Adserà and Ferrer (2014) and Adserà and Ferrer (2016) study the labour market outcomes of female immigrants to Canada.

13 There are several other papers that study language skill complementarities with other forms of human capital. Berman et al. (2003) and Torres (2013) find a positive interaction with occupational status/quality, and Chiswick and Miller (2003) show that there exist complementarities between language skills and foreign schooling and experience. Sharaf (2013) shows that education-job mismatches are linked to proficiency in the local language. To our knowledge, this current paper is the first to consider the impact of language proficiency on occupational skill transferability. 


\section{The model}

In the empirical analyses that follow this section, we strive to understand the transferability of immigrant workers' actual skill endowments, which are unobservable, by examining the skill requirement variables of pre- and postimmigration occupations. To guide the analysis, we first develop a skillsbased model of the transferability of immigrants' occupational skills to the host country labour market and derive testable predictions about the skill requirements of immigrants' host country jobs. We model the post-immigration occupational choice of an immigrant with exogenous skill endowments and proficiency in the dominant language of the host country. We assume that language plays an important role in the transferability of an immigrant's portfolio of occupational skills. This generates discrepancies between the skills required on the job and the ones with which immigrants are endowed. Furthermore, we assume that the impact of language on skill transferability is asymmetric across skills; i.e., the lack of language proficiency is more detrimental to the transferability of cognitive skills than of manual skills, so that immigrants with language difficulties end up in less skill intensive and seemingly less suitable occupations.

Our model is closely related to Lazear's (2009) two-skill, two-period model of skill-specific human capital. Gathmann and Schönberg (2010) propose a related skill and task-based model of human capital that features skill accumulation and occupational choice. Representing a firm (equivalently, a job or an occupation) as a production function that aggregates the analytical and manual skills of (or tasks performed by) the incumbent worker is a common modelling choice in a theory of occupational skills. We select an appropriate functional form so that task-specific human capital is less transferable between occupations that are dissimilar in terms of the combination of tasks used as inputs in the production process. We show in our framework that the interaction of skill transferability and language proficiency leads to gaps in the skill requirements of pre- and post-immigration jobs.

Immigrant workers: Immigrants bring different levels and combinations of source country skills. Suppose there are two types of skills: let $\bar{m}_{i}$ and $\bar{c}_{i}$ denote immigrant $i$ 's fixed endowments of manual and cognitive skills, respectively, at the time of arrival. An immigrant is also characterized by their fluency in the dominant language: let $L_{i}(t) \in[0,1]$ be an index of immigrant $i$ 's language ability, where $t \geq 0$ denotes time since migration. $L_{i}(t)=1$ reflects perfect language ability and $L_{i}(t)=0$ indicates the absence of any language ability in the dominant language. Language proficiency presumably improves with time spent in the host country. Accordingly, we assume that an immigrant's language deficiency, $1-L_{i}(t)$, is subject to exponential decay:

$$
\frac{d\left[1-L_{i}(t)\right]}{d t}=-\lambda\left[1-L_{i}(t)\right], \quad \lambda>0 .
$$

The solution to this differential equation is 


$$
1-L_{i}(t)=e^{-\lambda t}\left(1-L_{i}(0)\right)
$$

where $L_{i}(0) \in[0,1]$ is the index of immigrant $i$ 's dominant language fluency at the time of arrival.

Skill transferability: A lack of dominant language ability might impede the full utilization of immigrants' skills in the host country labour market. To incorporate this into the model, define

$$
c_{i}(t)=\left[1-\eta_{c}\left(1-L_{i}(t)\right)\right] \bar{c}_{i}, \quad \eta_{c} \in[0,1]
$$

as "host country usable" cognitive skills. Converting "source country usable" skills, $\bar{c}_{i}$, into host country usable skills depends on the immigrant's fluency in the host country's dominant language. Host country usable skills are increasing in language ability, $L_{i}(t)$, and in source country usable skills, $\bar{c}_{i}$, and there is some minimum portion of source country usable skills, $\left(1-\eta_{c}\right) \geq 0$, that can be transferred even without any dominant language ability. With perfect language ability, cognitive skills are perfectly transferable.

Similarly, define "host country usable" manual skills according to

$$
m_{i}(t)=\left[1-\eta_{m}\left(1-L_{i}(t)\right)\right] \bar{m}_{i}, \quad \eta_{m} \in[0,1] .
$$

It is not necessarily the case that the impact of language proficiency on skill transferability is symmetric: i.e., that $\eta_{m}=\eta_{c}$. In fact, we impose the restriction that $\eta_{m}<\eta_{c}$; manual skill transferability is less sensitive to language proficiency than cognitive skill transferability. There is reason to believe that performing manual-type tasks on-the-job does not typically necessitate a mastery of the dominant language, whereas activities that require cognitive ability are more likely to be carried out in the dominant language and thus require the job incumbent to communicate effectively.

Combining the measures of host country usable skills, (3) and (4), with the evolution of language proficiency, (2), yields

$$
\begin{aligned}
c_{i}(t) & =\left[1-\eta_{c} e^{-\lambda t}\left(1-L_{i}(0)\right)\right] \bar{c}_{i}, \\
m_{i}(t) & =\left[1-\eta_{m} e^{-\lambda t}\left(1-L_{i}(0)\right)\right] \bar{m}_{i} .
\end{aligned}
$$

Immigrants convert source country occupational skills into host country usable skills as they become more familiar with the dominant language such that perfect skill transferability is achieved only in the limit: ${ }^{14}$

$$
\lim _{t \rightarrow \infty}\left\{m_{i}(t), c_{i}(t)\right\}=\left\{\bar{m}_{i}, \bar{c}_{i}\right\}
$$

14 Setting the upper bounds equal to source country usable skill levels rules out post-migration skill accumulation. This may not be viewed as too restrictive given that we focus our attention on the short-term following arrival. 
Occupations: Occupations are heterogeneous in their use of skills; they combine skills in different proportions to produce output. The time $t$ wage for worker $i$ employed in occupation $j$ is given by ${ }^{15}$

$$
y_{i j}(t)=\left(\frac{c_{i}(t)}{\alpha_{j}}\right)^{\alpha_{j}}\left(\frac{m_{i}(t)}{1-\alpha_{j}}\right)^{1-\alpha_{j}}
$$

where $\alpha_{j} \in[0,1]$ is the characteristic of the occupation. The terminal source country wage is similarly defined, but with source country usable skills as inputs:

$$
\bar{y}_{i j}=\left(\frac{\bar{c}_{i}}{\alpha_{j}}\right)^{\alpha_{j}}\left(\frac{\bar{m}_{i}}{1-\alpha_{j}}\right)^{1-\alpha_{j}} .
$$

Occupational sorting: The above setup implies that immigrants are compensated not only for their host country usable skills but also for the suitability of the occupation-worker match. In other words, a worker's earnings vary according to how closely their skill portfolio aligns with the occupation's demand for skills. Consequently, at any $t \geq 0$, an immigrant selects the occupation that maximizes current wage earnings. Maximizing (8) with respect to $\alpha_{j}$ yields

$$
\alpha_{i}^{*}(t)=\frac{c_{i}(t)}{c_{i}(t)+m_{i}(t)},
$$

which defines the occupation that produces an ideal match for an immigrant worker of type $\left\{m_{i}(t), c_{i}(t)\right\}$ at time $t$. The solid line in figure 1 displays the wage for a particular immigrant worker in different occupations (i.e., for any $\alpha \in[0,1])$. The wage is normalized by dividing by $c_{i}(t)+m_{i}(t)$ so that the wage in occupation $\alpha_{i}^{*}(t)$ is unity. An immigrant with relatively high cognitive ability would be more productive in an occupation with a correspondingly high $\alpha$, while immigrants with more manual skills would be better suited for a low $\alpha$ job.

Language deficiencies not only lower the absolute levels of skills from $\left\{\bar{c}_{i}, \bar{m}_{i}\right\}$ to $\left\{c_{i}(t), m_{i}(t)\right\}$ but can also affect the skill ratio:

$$
\eta_{m}<\eta_{c} \quad \Longleftrightarrow \quad \alpha_{i}^{*}(t)=\frac{c_{i}(t)}{c_{i}(t)+m_{i}(t)}<\frac{\bar{c}_{i}}{\bar{c}_{i}+\bar{m}_{i}}=\bar{\alpha}_{i}^{*} .
$$

For example, a German advertising and promotions manager might be better suited for a position as a graphic designer in Canada if a lack of English/French language fluency affects their ability to convey information to clients without

15 The choice of wage equation mirrors the skill aggregation function in Phelan's (2013) model of wage loss among displaced workers. The critical implication is that workers are more productive if their skill ratios align with the skill weights. In contrast, other papers in the skill and task-based human capital literature assume functional forms that lead workers to choose occupations that rely the most on their best skill (Lazear 2009, Gathmann and Schönberg 2010). 


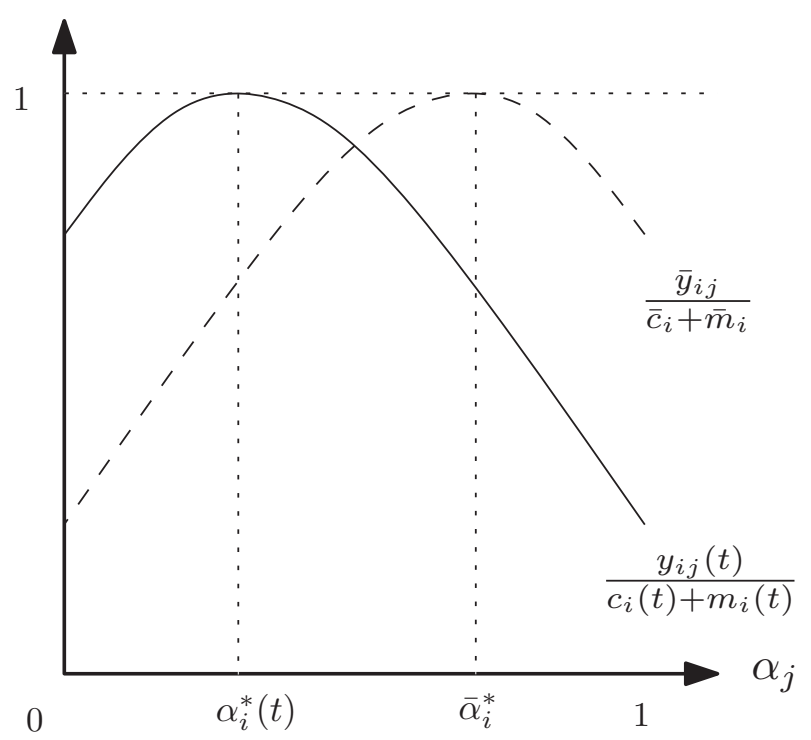

FIGURE 1 The (normalized) source country wage (dashed line) and host country wage (solid line) for worker $i$ in occupation $j$ when $L_{i}(t)<1$ and $\eta_{m}<\eta_{c}$

affecting their ability to develop graphics and illustrations. Figure 1 depicts this result for an immigrant with imperfect language ability, $L_{i}(t)<1$. The ideal occupation in the source country is characterized by $\bar{\alpha}_{i}^{*}$, but $\alpha_{i}^{*}(t)<\bar{\alpha}_{i}^{*}$ is the appropriate occupational choice after spending time $t$ in the host country because of the interaction between language fluency and skill transferability.

Since language ability affects cognitive and manual skill gaps asymmetrically, this implies that the ideal occupation match, $\alpha_{i}^{*}(t)$, is constantly shifting. If immigrant worker $i$ can costlessly and constantly shift to a new and more suitable occupation, the wage at every point in time will satisfy $y_{i}^{*}(t)=c_{i}(t)+m_{i}(t)$. Wages therefore evolve according to

$$
y_{i}^{*}(t)=e^{-\lambda t} y_{i}^{*}(0)+\left(1-e^{-\lambda t}\right) \bar{y}_{i}^{*},
$$

where $\bar{y}_{i}^{*}=\bar{c}_{i}+\bar{m}_{i}$ is the terminal source country wage, which is also the wage in the host country labour market if source country usable skills were perfectly transferable. Of course, continuously shifting from one occupation to another is infeasible in an actual labour market. ${ }^{16}$ It might be more reasonable to expect wage growth to approximate (12) but with discrete jumps in wages at every occupational switch.

Equations (2), (5), (6) and (12) describe the evolution of language, host country usable occupational skills and wages. Figure 2 provides a graphical

16 For evidence of frictions in the job search process of immigrants see Skuterud and $\mathrm{Su}$ (2012) and Bowlus et al. (2016). 


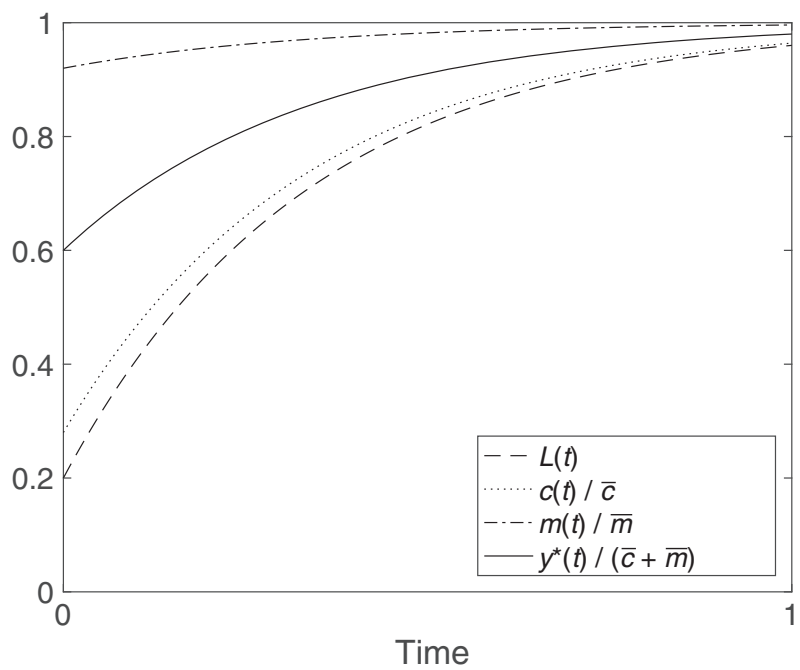

FIGURE 2 Language proficiency, wage and host country usable skills relative to source country counterparts

NOTE: For this example, $\bar{c}_{i}=\bar{m}_{i}=1, L_{i}(0)=1 / 5, \eta_{m}=1 / 10, \eta_{c}=9 / 10$ and $\lambda=3$.

representation of the process of labour market assimilation for a numerical example with $\bar{c}_{i}=\bar{m}_{i}=1, L_{i}(0)=1 / 5, \eta_{m}=1 / 10, \eta_{c}=9 / 10$ and $\lambda=3$. Skill gaps diminish over time as enhanced dominant language ability allows more source country usable skills to be applied in the host country economy. As a consequence, immigrants experience wage growth. The model also implies occupational transitions to jobs that more closely resemble source country occupations in terms of their occupational skill requirements.

The two empirical implications of the model are summarized below.

1. Skill gaps: Limited language proficiency gives rise to mismatches between the skill requirements of source country and host country occupations. Under the assumption that $\eta_{m}<\eta_{c}$, immigrants who lack fluency in the dominant language will be more productive in an occupation that differs from their source country occupation. In particular, language difficulties should cause wider cognitive skill gaps relative to the corresponding manual skill gaps.

2. Language acquisition: To the extent that language ability improves with time since migration, the skill gaps for an immigrant cohort should diminish over time. In addition, immigrants less proficient in the dominant language at the time of arrival should experience more dramatic reductions in skill gaps with time in the host country.

In the subsequent sections, we inquire as to whether the predictions from the above simple model of immigrants' occupational choices are consistent with the data. 


\section{Occupation and immigration data}

We use the recently developed methodology introduced by Ingram and Neumann (2006), Poletaev and Robinson (2008), Bacolod and Blum (2010) and Yamaguchi (2012) to reduce the abundant list of job characteristics in the Occupation Information Network (O*NET) into a small number of fundamental skill requirements. More specifically, we apply factor analysis techniques to the $\mathrm{O}^{*} \mathrm{NET}$ data in order to generate a vector of skills necessary to perform the job tasks associated with each occupation. The skill portfolios include both cognitive skills (analytical and interpersonal skills) as well as manual skills (fine motor skills, visual skills and physical strength). We then match the source and host country occupations from the LSIC to the skill measures generated from the O*NET data in order to assign them skill requirements. Then, by comparing pre- and post-immigration occupations, we determine how well these jobs match in terms of the skills required to perform job tasks. Occupational skill mismatch could be driven by language fluency, as in the model presented in section 2 , as well as a variety of other factors. In addition to language proficiency, we consider several alternative skill gap interpretations: unrecognized credentials or foreign work experience, insufficient knowledge of the local labour market, underdeveloped social networks and discrimination.

\subsection{Longitudinal Survey of Immigrants to Canada (LSIC)}

The main dataset used for the analysis of immigrant outcomes is the LSIC. This survey was designed to provide information on new immigrants' adjustment to life in Canada. The full survey sample consists of immigrants who arrived in Canada between October 1, 2000, and September 30, 2001, and were 15 years of age or older at the time of landing. It is a longitudinal survey with immigrants being interviewed at six months, two years and four years after landing in Canada. ${ }^{17}$ Individuals who applied and landed from within Canada are excluded from the original survey, since their arrival in Canada may have occurred far in advance of the official landing and the survey is designed to capture the initial social and economic integration of immigrants. Refugees claiming asylum from within Canada were not surveyed. To create a sample representative of newcomers, we drop a small percentage of immigrants who had previously been in Canada on a work or student visa. We restrict our sample to immigrants of age 25 to 59 at the time of the first cycle to reduce any effects of education or retirement decisions.

A unique feature of the LSIC data is that it contains information on entry class. While the majority of legal immigrants enter the US under the family reunification program, the majority of immigrants to Canada enter under

17 For the sake of brevity, we present the estimates for six months and four years after landing. We find that the second-year skill gap estimates tend to be between the six month and four year estimates. 
the economic class. ${ }^{18}$ Canada, like Australia and New Zealand, uses pointsbased selection criteria to admit the principal applicant (formally labelled skilled worker principal applicant) of the family entering under the economic class. ${ }^{19,20}$ We are able to identify the skilled worker principal applicants: the immigrants whose human capital was directly assessed by an immigration officer. The majority of our sample (67\%) are skilled worker principal applicants. $^{21}$

The LSIC provides three digit occupation codes for both source country occupation and the first four years of occupations since immigrating. ${ }^{22}$ One shortcoming of the data is that source country employment information is incomplete, as we do not know the duration of source country employment or the date of termination. Human capital may depreciate with the passage of time between source country employment and migration. We determine language fluency using the following LSIC questions: "How well can you speak English?" and "How well can you speak French?" The choice of language to determine fluency is based on the dominant language of the place of residence

18 Economic immigrants are also admitted under the investor and entrepreneur classes. See Beach et al. (2007), Sweetman and Warman (2013), Sweetman and Warman (2014) and Warman et al. (2019) for an overview of the Canadian program and a description of the composition of immigrants' admission class.

19 Canada has made recent changes to the immigration program to address the worsening outcomes of economic immigrants and to better meet regional needs. Skilled worker applicants are now required to have at least one of the following: pre-arranged employment in Canada, work experience in an occupation that appears on a list of in-demand jobs, a recent PhD degree from a Canadian university or current $\mathrm{PhD}$ student status in Canada. The Canadian Experience Class was introduced, under which former temporary foreign workers and international students are admitted conditional on meeting certain criteria. The Provincial Nominee Program has also greatly expanded. Canadian provinces can select immigrants based on self-defined local needs and admit them as provincial nominees. Starting in 2015, economic immigrants must apply through the Express Entry (EE) system, under which the highest ranked candidates are invited to apply for permanent residency. Currently under the EE, half of the available points are awarded for arranged employment.

20 While the US does not have a point system, there has been discussion about the possibility of adopting one (Beach 2006). See Belot and Hatton (2012) for an overview of the immigrant selection criteria of OECD countries.

21 Over the period covered by the data, around $60 \%$ of new immigrants entered under the economic class. Of these, only the principal applicant is assessed under the point system, so that skilled worker principal applicants typically represent only $20 \%$ to $25 \%$ of immigrants. Since most skilled worker principal applicants are working age males landing from abroad, our sample is comprised of a much larger percentage of them.

22 The LSIC contains information for all jobs in Canada. We focus our analysis on the main job as indicated by the respondent in each of the three cycles. 
of the immigrant (English, French or bilingual location). For bilingual locations, we use the language in which the immigrant has the highest ability. We use responses to these language questions ${ }^{23}$ to generate four language categories: (i) "cannot speak this language" or can speak this language "poorly" or "fairly well," (ii) can speak this language "well," (iii) can speak this language "very well" and (iv) this language is my "mother tongue."

\subsection{Census of population}

Our ability to study smaller subsamples of respondents is limited by the LSIC sample size. We therefore augment our analysis using the 2006 Census to examine immigrants from OECD countries separately for the different language usage and fluency groups. Unfortunately, the Census does not contain information on the source country occupation. We instead use detailed field of study and other human capital related information to predict plausible skill requirements of the source country occupation. ${ }^{24}$ To do so, we obtain coefficient estimates from a regression for the Canadian born between the ages of 30 and 65 . We then use the following equation to predict the source country occupational skill requirements of OECD immigrants in Canada given their field of study and other demographic controls:

$$
\hat{s}=\hat{\theta}_{0}+\hat{\theta}_{1} A g e+\hat{\theta}_{2} H i E d+\hat{\theta}_{3} A g e \times H i E d+\hat{\theta}_{4} F o S+X \hat{\beta},
$$

where Age is a set of age dummies, HiEd is a set of highest level of education dummies, FoS is a set of around 400 field of study dummies and $X$ is a vector of demographic controls (province of residence, marital status and children present in the Census family).

To mimic the LSIC sample in cycle 3, we restrict the sample of Census immigrants to those between the ages of 30 and 65 , but who immigrated between the ages of 25 to 59 (i.e., the 2000-2001 cohort). The resulting sample of immigrants closely approximates the cycle 3 (4 years after arrival)

23 A fraction of immigrants change their assessment of their own language ability in later cycles. Although many of these changes are likely due to immigrants improving their language ability with time in Canada, we also find that a non-negligible group of immigrants indicate a lower language ability in later cycles, with most changes occurring between cycles 1 and 2. When computing cycle 1 and cycle 3 mean values, we present the estimates computed with the cycle 2 language question responses to avoid the possible inaccurate initial language self-assessments. However, the mean gap estimates by language group are very similar when we instead use cycle 1 language questions to classify immigrants' language ability. A disadvantage of using the cycle 2 values is the possible overestimation of language ability at the time of entry for some other respondents. A very small fraction of the cycle 1 to cycle 2 changes is instead due to immigrants moving from one location to another where the other official language is dominant.

24 See Aydede and Dar (2016) for a study of occupational outcomes and matching quality based on field of study information from the Census. 
sample of the LSIC in terms of date of arrival, age at arrival and time in Canada. As we show in section 4.1, the predicted mean source country occupational skill requirements for the Census sample very closely match the mean occupational skill requirements imputed directly from the source country occupations disclosed by LSIC respondents.

To create language ability groups in the Census data, we use both language spoken at home and mother tongue. We construct five language categories: (i) "do not speak the local language," (ii) "do not speak the local language at home," (iii) "speak the local language regularly at home," (iv) "speak the local language most often at home" and (v) "local language is the respondent's mother tongue." For the subset of immigrants from OECD countries, we group those who "do not speak the local language" together with those who "do not speak the local language at home" given the small number of respondents in the first group.

\subsection{Constructing skill indices from $0^{*}$ NET}

Studies of the occupational mobility of immigrants (Green 1999, CohenGoldner and Eckstein 2010) have divided occupations into two or three broad categories: white collar, blue collar and professional. Aggregating in this manner ignores the many differences between occupations within each category. While finer classification systems (Warman et al. 2015) reduce within category variation, there is no conceivable method to rank the magnitude of an occupation switch between categories in terms of the human capital requirements. Recently, researchers have circumvented these shortcomings by characterizing occupations based on the tasks required to perform the job. Ingram and Neumann (2006) and others have applied factor analysis to the Dictionary of Occupational Titles (DOT) in order to describe each occupation in terms of the skill set required to accomplish the job tasks.

$\mathrm{O}^{*} \mathrm{NET}$, which replaced DOT, is a useful source of detailed and comprehensive information about hundreds of jobs (1,122 occupational units in total). The dataset contains information on formal education, job training and other qualifications necessary for each occupation, as well as different abilities and categories of knowledge required by its workers. Much of this information can be used to determine the portfolio of skills needed for each job. For example, some jobs require numerical abilities and knowledge of arithmetic, algebra and statistics. One would expect workers in such jobs to possess advanced analytical skills. Other O*NET information includes aptitudes, temperaments, tasks and environmental conditions, which can also imply certain skill requirements. For example, some occupations involve moving and handling objects and performing activities such as climbing and lifting, which suggest the need for physical strength.

We use factor analysis to reduce the dimensionality of the occupation information contained in $\mathrm{O}^{*} \mathrm{NET}$. The underlying assumption is that the large set of $\mathrm{O}^{*} \mathrm{NET}$ job characteristics can be summarized by a small number of 
fundamental skill requirements. Factor analysis and principal component analysis are the techniques that Ingram and Neumann (2006), Bacolod and Blum (2010) and Poletaev and Robinson (2008) applied to DOT. Methodological difficulties arise because determining the appropriate number of factors and interpreting the factors as particular skills is somewhat arbitrary. Moreover, multivariate factor analysis reduces the large set of $\mathrm{O}^{*} \mathrm{NET}$ characteristics into a small number of orthogonal skills, which does not allow skill requirements to be correlated.

We propose a slight variation in the methodology, known as confirmatory factor analysis, which is similar to the approach used by Yamaguchi (2012). We separate the O*NET variables a priori into groups of job characteristics such that all attributes in each group are associated with a common skill component. Our polychotomy includes interpersonal skills, analytical skills, fine motor skills, physical strength and visual skills. Then, we estimate the principal component of each group of variables separately, assuming that a single factor underlies each group. The output of this process provides a way to check which of the variables chosen from $\mathrm{O}^{*} \mathrm{NET}$ are in fact contributing to the score associated with each skill: high factor loadings are needed to confirm that the variables selected a priori are represented by the principal component. Only variables with factor loadings above 0.8 are kept. While this is a somewhat arbitrary cutoff, it implies that for each of the O*NET variables used in the analysis, most (almost two thirds, or $0.8^{2}=0.64$ ) of the variance is explained by the factor. Iteratively dropping variables that fail to contribute to the factor of interest yields a score for each job that reflects the occupational requirement for the underlying skill. Technical appendix $\mathrm{B}$, available in the online version of this article, contains descriptions of the relevant $\mathrm{O}^{*} \mathrm{NET}$ variables and the output from factor analysis. The resulting portfolio of skills is much easier to interpret than the principal component method used in some papers. Moreover, this methodology drops the unrealistic assumption that the underlying skills are orthogonal. ${ }^{25}$

By construction, the scores yielded have mean zero and unit variance. We use the occupational distribution of the Canadian population in the 2001 Census master file as a weight for the factor analysis. This provides convenient intuition so that the unit of a derived factor score is equal to one standard deviation in the skill distribution for the Canadian population. The estimated factor scores are then applied to the occupations of recent immigrants to Canada contained in the LSIC data. ${ }^{26}$

25 This method of constructing skill requirements is also used as a robustness check in Bacolod and Blum (2010) as an alternative way of constructing skill indices.

26 The LSIC occupations are classified according to the Standard Occupational Classification (SOC 1991), which uses a four-character, alpha-numeric coding system. O*NET classifies occupations according to a six-digit O*NET-SOC coding system. We manually map LSIC occupation codes into the O*NET-SOC classification by matching information from the occupation labels for both 


\subsection{Methodological remarks}

It is important to acknowledge some of the caveats of the methodology described above. First, skills may vary even within an occupation. For a given occupation, it is not possible for us to determine where a worker (immigrant or Canadian) is in the skill distribution. Fortunately, O*NET contains information for over 1,100 jobs that are matched to almost 500 LSIC jobs, so the within-occupation variation should be minute compared to other broader occupation classifications. The longitudinal analysis focusing on occupations gives rise to a further complication due to the possibility of measurement error. Respondents may change the label of their occupation from year to year, which can be misinterpreted as an occupational switch. Our analysis circumvents this problem to a large degree for several reasons. First, respondents are asked to specify their source country job and their occupations during the first six months in Canada in the same interview. Moreover, the two subsequent interviews are only a year-and-a half and three-and-a-half years later. Second, if immigrants happen to mislabel their occupations, it is likely that they will report an occupation that is similar in terms of skill requirements, which reduces measurement error relative to analyses that identify switches using occupation codes.

There is a potential for measurement error when we ascribe the O*NETderived skill requirements to Canadian occupations when in fact the $\mathrm{O}^{*} \mathrm{NET}$ data is based on occupations in the US. Doing so implicitly assumes that occupations in Canada require similar skills to those in the US. We then impose a second and more questionable assumption that all source country occupations are similar in skill requirements to the corresponding occupations in the US. Given the similarities between the American and Canadian economies, the first assumption seems plausible. In contrast, there are bound to be differences in the skill requirements of occupations in some countries. ${ }^{27}$ These discrepancies are potentially less severe among OECD countries. Whenever the data allow, we present results for the subsample of immigrants from OECD countries. Exploratory evidence obtained from the full sample relies to some extent on the assumption that cross-country differences in the skill requirements of occupations are not too great, and these results should therefore be interpreted with caution (i.e., keeping in mind the potential measurement error introduced by applying the O*NET data to other countries). For example, our approach

systems as well as the sample of reported job titles included in $\mathrm{O}^{*} \mathrm{NET}$. We are able to successfully match over $95 \%$ of the LSIC occupations in our sample.

27 A similar issue in the context of immigration policy is the absence of any distinction between credentials of different qualities among Canadian immigrants. To address this, Canada recently implemented policy changes to directly examine the quality of applicants' credentials. 
could result in overestimated source country cognitive skills and underestimated manual skills for certain non-OECD countries and consequently overstate the severity of skill mismatch.

Drawing conclusions about the transferability of skills to the Canadian labour market relies on the additional assumption that an immigrant's skill endowments closely resemble the skill requirements of their source country occupation. Even in the source country where dominant language proficiency is a less common issue, we should acknowledge the possibility that other frictions prevent perfect matching between workers and occupations so that the skill requirements of the source country occupation do not altogether align with the immigrant's actual skills. On the other hand, the last job held by an immigrant prior to migration is likely the result of a lengthy process of human capital accumulation (e.g., formal education) as well as matching and sorting into a suitable occupation. We therefore argue that the skill content of a source country occupation should provide a reasonable description of a worker's actual skill endowments, and the presence of a skill gap likely reflects a mismatch in the Canadian economy rather than abroad.

Alternatively, one can think of the skill portfolio of a source country occupation as potentially reflecting an immigrant's expected skill levels upon landing if they could have taken a job in the same occupation they held in their source country. This is particularly relevant for skilled worker principal applicants because, as noted previously, they are assessed and selected based on their source country human capital, including aspects directly and indirectly related to their pre-application occupation. Under this interpretation, concerns about how accurately $\mathrm{O}^{*} \mathrm{NET}$ reflects the skill requirements of source country occupations are non-issues.

It is worth pointing out that the data shortcomings acknowledged above are not new to the immigration literature. Consider, for example, the highest educational degree attained as a common measure of immigrants' human capital. Within-category variation in the quality of education, discrepancies in school system quality across countries and unobserved heterogeneity are all cause for concern. Our methodology does not circumvent these empirical challenges, but it does provide a novel perspective on the cross-border transferability of human capital. Our finely partitioned occupational skill vectors provide an alternative assessment of an immigrant's human capital that is multidimensional and potentially more up-to-date. ${ }^{28}$

28 In contrast, highest educational degree attained is very broad and one-dimensional. Moreover, the response to an education-related question remains the same even as a worker accumulates skills and progresses along a career path. 


\section{Sample statistics and estimation results}

\subsection{Skill gaps}

Table 1 displays the skill content of occupations held by immigrant men in Canada, which is compared to that of their source country occupations. Recall that each factor is constructed such that zero represents the average for the Canadian population, and the units are standard deviations of the Canadian

\section{TABLE 1}

Mean skill requirements of source country and Canadian occupations

\begin{tabular}{|c|c|c|c|c|c|c|}
\hline & \multicolumn{3}{|c|}{ OECD countries } & \multicolumn{3}{|c|}{ All countries } \\
\hline & $\begin{array}{c}\text { LSIC } \\
6 \text { months }\end{array}$ & $\begin{array}{c}\text { LSIC } \\
4 \text { years }\end{array}$ & $\begin{array}{c}2006 \text { Census } \\
2000-2001 \\
\text { cohort }\end{array}$ & $\begin{array}{c}\text { LSIC } \\
6 \text { months }\end{array}$ & $\begin{array}{c}\text { LSIC } \\
4 \text { years }\end{array}$ & $\begin{array}{c}2006 \text { Census } \\
2000-2001 \\
\text { cohort }\end{array}$ \\
\hline $\begin{array}{l}\text { Source } \\
\text { Canadian } \\
\text { Difference }\end{array}$ & $\begin{array}{c}\text { Interpersol } \\
0.63 \\
0.13 \\
-0.50^{* *} \\
(0.08)\end{array}$ & $\begin{array}{l}\text { al } \\
\quad 0.66 \\
0.41 \\
-0.25^{* *} \\
(0.07)\end{array}$ & $\begin{array}{c}0.71 \\
0.42 \\
-0.29^{* *} \\
(0.02)\end{array}$ & $\begin{array}{c}0.70 \\
-0.35 \\
-1.05^{* *} \\
(0.03)\end{array}$ & $\begin{array}{c}0.71 \\
0.00 \\
-0.71^{* *} \\
(0.02)\end{array}$ & $\begin{array}{c}0.84 \\
0.20 \\
-0.64^{* *} \\
(0.01)\end{array}$ \\
\hline $\begin{array}{l}\text { Source } \\
\text { Canadian } \\
\text { Difference }\end{array}$ & $\begin{array}{c}\text { Analytical } \\
0.91 \\
0.42 \\
-0.49^{* *} \\
(0.10)\end{array}$ & $\begin{array}{c}0.99 \\
0.65 \\
-0.34^{* *} \\
(0.08)\end{array}$ & $\begin{array}{c}1.02 \\
0.65 \\
-0.38^{* *} \\
(0.02)\end{array}$ & $\begin{array}{c}1.13 \\
-0.07 \\
-1.20^{* *} \\
(0.03)\end{array}$ & $\begin{array}{c}1.14 \\
0.32 \\
-0.82^{* *} \\
(0.03)\end{array}$ & $\begin{array}{c}1.21 \\
0.54 \\
-0.67^{* *} \\
(0.01)\end{array}$ \\
\hline $\begin{array}{l}\text { Source } \\
\text { Canadian } \\
\text { Difference }\end{array}$ & $\begin{array}{c}\text { Fine moto } \\
-0.29 \\
0.03 \\
0.31^{* *} \\
(0.07)\end{array}$ & $\begin{array}{c}-0.37 \\
-0.16 \\
0.22^{* *} \\
(0.08)\end{array}$ & $\begin{array}{c}-0.35 \\
-0.18 \\
0.17^{* *} \\
(0.02)\end{array}$ & $\begin{array}{c}-0.28 \\
0.25 \\
0.53^{* *} \\
(0.03)\end{array}$ & $\begin{array}{c}-0.32 \\
0.13 \\
0.45^{* *} \\
(0.02)\end{array}$ & $\begin{array}{c}-0.48 \\
-0.07 \\
0.42^{* *} \\
(0.01)\end{array}$ \\
\hline $\begin{array}{l}\text { Source } \\
\text { Canadian } \\
\text { Difference }\end{array}$ & $\begin{array}{c}\text { Visual } \\
-0.12 \\
0.12 \\
0.24^{* *} \\
(0.07)\end{array}$ & $\begin{array}{c}-0.16 \\
-0.01 \\
0.16^{* *} \\
(0.07)\end{array}$ & $\begin{array}{c}0.15 \\
0.07 \\
-0.08^{* *} \\
(0.02)\end{array}$ & $\begin{array}{c}-0.09 \\
0.10 \\
0.20^{* *} \\
(0.02)\end{array}$ & $\begin{array}{c}-0.12 \\
0.09 \\
0.21^{* *} \\
(0.02)\end{array}$ & $\begin{array}{l}0.10 \\
0.18 \\
0.08^{* *} \\
(0.01)\end{array}$ \\
\hline $\begin{array}{l}\text { Source } \\
\text { Canadian } \\
\text { Difference }\end{array}$ & $\begin{array}{c}\text { Physical st } \\
-0.44 \\
-0.10 \\
0.35^{* *} \\
(0.08)\end{array}$ & $\begin{array}{l}\text { ength } \\
-0.54 \\
-0.30 \\
0.24^{* *} \\
(0.08)\end{array}$ & $\begin{array}{c}-0.50 \\
-0.24 \\
0.26^{* *} \\
(0.02)\end{array}$ & $\begin{array}{c}-0.49 \\
0.22 \\
0.72^{* *} \\
(0.03)\end{array}$ & $\begin{array}{c}-0.53 \\
0.02 \\
0.55^{* *} \\
(0.02)\end{array}$ & $\begin{array}{c}-0.66 \\
-0.20 \\
0.46^{* *} \\
(0.01)\end{array}$ \\
\hline Observations & 149 & 157 & 2,090 & 1,476 & 1,927 & 13,940 \\
\hline
\end{tabular}

NOTES: Standard errors are in parentheses. Level of significance between Canadian and source country occupational skill requirement denoted by ${ }^{* *} p<0.01,{ }^{*} p<0.05,{ }^{+} p<0.1$. LSIC sample based on workers with positive earnings and non-missing source and host country occupation codes. Sample restricted to males aged 24 to 59 at the time of cycle 1 . Census sample based on immigrants with positive earnings in 2006. Sample restricted to males aged 30 to 65 , but that immigrated between the ages of 25 and 59. Predicted source country occupational skill requirements (as per equation (13)) are reported as source country measures (and used in calculating differences). 
skill requirement distribution. Columns 1 and 4 show the skill requirements of cycle 1 occupations from the LSIC (six months after landing in Canada), while columns 2 and 5 show the content of cycle 3 occupations from the LSIC (around four years after landing in Canada). Columns 3 and 6 are constructed from the 2006 Census for the 2000-2001 cohort (around four or five years after arrival).

We begin by examining the skill gaps computed for immigrants from OECD countries (columns 1 to 3). As previously discussed, OECD countries are likely similar in terms of production technologies, labour market institutions and hence occupational skill requirements. The means displayed in table 1 reveal that immigrants from OECD countries tend to work in occupations with very high cognitive skill requirements in the source country. The set of source country occupations for the OECD sample suggests that interpersonal and analytical skill requirements are on average 0.63 and 0.91 standard deviations above the average for the Canadian workforce, respectively. When they first arrive in Canada (column 1), they end up working in jobs that require cognitive skill requirements that are still higher than the Canadian average, but lower than what one might expect given their source country job titles. More specifically, OECD immigrants acquire jobs upon arrival that require interpersonal skills only 0.13 standard deviations above the Canadian average and analytical skills 0.42 standard deviations above the average. The resulting cognitive skill gaps are around half of a standard deviation for both interpersonal and analytical skills.

In contrast, the manual skill requirements of OECD immigrants' jobs after landing in Canada are more than those of their source country occupations. The requirement for fine motor skills increases from 0.29 standard deviations below the Canadian average for source country occupations to around the Canadian average; this represents a move of nearly one third of a standard deviation up the skill distribution. The visual skill requirement increases from 0.12 standard deviations below the Canadian average to 0.12 above, while the strength requirement increases from 0.44 standard deviations below to only 0.10 below the Canadian average. Overall, immigrants from OECD countries appear to work in jobs after landing that require much lower cognitive skills but much higher manual skills compared to their source country occupations.

To check for signs of convergence in skill requirements among OECD immigrants to Canada, we report the skill gap between source country occupations and cycle 3 Canadian occupations (four years after landing) in column 2 . The decline in cognitive skill gaps is particularly noteworthy: the interpersonal skill gap decreases from 0.50 to 0.25 standard deviations and the analytical skill gap drops from 0.49 to 0.34 standard deviations. Even though the cognitive skill gaps persist, there is evidence that immigrants gradually move to jobs that utilize their interpersonal and analytical skills. There appear to be modest declines in manual skill gaps as well: the fine motor skill gap drops from 0.31 to 0.22 standard deviations, the visual skill gap shrinks from 0.24 to 0.16 
standard deviations and the strength gap falls from 0.35 to 0.24 standard deviations.

The mean skill requirements for the 2000-2001 cohort of OECD immigrants in the 2006 Census are presented in column 3 of table 1. As detailed above, the Census sample should be comparable to the LSIC sample four years after arrival. The estimates are remarkably similar to those presented in column 2 . The source country values are almost identical for interpersonal skills (0.71 versus 0.66$)$, analytical skills $(1.02$ versus 0.99$)$, fine motor skills $(-0.35$ versus $-0.37)$ and physical strength $(-0.50$ versus -0.54$)$. For visual skills, the source country averages are not identical, but nevertheless comparable ( 0.15 versus -0.16). The skill requirements associated with their employment in Canada, and consequently the skill differences, are also very similar for all five of the skills. These similarities arise despite not having information on source country occupation in the Census, which lends some support to the methodology described above involving predicted source country occupational skill requirements based on education, field of study, age and other demographic characteristics.

The OECD means from columns 1 to 3 of table 1 suggest that occupational skill gaps exist and persist even among immigrants from advanced economies. Columns 4 to 6 of table 1 contain the same estimates, but for the full sample of immigrants. Overall, the same qualitative pattern emerges for both the OECD sample and the full sample. In particular, there are negative cognitive skill gaps and positive manual skill gaps. The magnitudes are especially large initially (over one standard deviation for both cognitive skills), and the mismatch implied by our analysis persists even after four years in Canada. ${ }^{29}$ The severity of the occupational skill mismatch appears to be more extreme for the full sample of immigrants. As discussed above, one possibility is that the information from $\mathrm{O}^{*} \mathrm{NET}$ does not perfectly reflect the skill content of occupations for all countries. It is altogether possible that the methodology overestimates cognitive skill requirements and underestimates manual skill requirements and hence exaggerates the skill gaps among immigrants from countries with less technology and knowledge oriented economies. While there are other reasons to expect better skill transferability among immigrants from similar and advanced economies, ${ }^{30}$ one should be cautious when assessing the severity of skill immobility based on unconditional results that universally

29 Changes in Canadian skill requirements between cycles 1 and 3 can manifest as a result of changes in the composition of the sample studied; the sample increases from 1,476 to 1,927 due to delays in entering the workforce. Despite the large jump in sample size between cycles, there is very little change in average source country occupational skill requirements. Further, when we estimate the gaps for the balanced sample, the gaps are very similar to those in columns 4 and 5 of table 1 (see table A1 in the technical appendix, available in the online version of this article).

30 For example, the smaller gaps for the OECD subsample could be due to differences in incentives to immigrate; i.e., a potential OECD emigrant is 
apply the skill requirements derived from $\mathrm{O}^{*} \mathrm{NET}$. At the very least, the skill gaps reported in table 1 contribute to our understanding and measurement of the difference between the labour market experience of an immigrant in Canada and the reported title of their source country occupation. Even if there are non-negligible discrepancies between the true source country skill requirements and the values imputed from $\mathrm{O}^{*} \mathrm{NET}$, the skill gaps provide a sense of how far (in units of skills normalized to the Canadian distribution of skill requirements) a foreign-trained engineer is from an engineering job in Canada, for example.

We re-estimate the means separately for skilled worker principal applicants and non-economic class immigrants (defined as family and humanitarian class immigrants ${ }^{31}$ ). We find that the skilled worker principal applicants work in source country occupations with much higher cognitive skill requirements and much lower manual skill requirements. However, despite being admitted based on economic criteria, they are no more successful in terms of skill mobility. While some of the gaps between the source and host country occupational skill requirements are similar to non-economic class immigrants, the skilled worker principal applicants suffer much larger gaps in terms of the analytical skill and strength requirements in particular. We report the skill gaps for skilled worker principal applicants and non-economic class immigrants in table 2. In the same table, we examine the gaps for the small group of immigrants with prearranged employment (less than $5 \%$ of the sample). They tend to more closely match source country skill requirements and therefore experience smaller skill gaps than is true for the full sample. This might support the policy changes in 2013 that made pre-arranged employment a key component for admittance for skilled worker principal applicants, ${ }^{32}$ although we do not know how long it took each applicant to find and arrange employment from abroad prior to landing in Canada.

In figure 3 , we present the density estimates for the various O*NETderived skill requirements of source country occupations and the occupations six months and four years after arrival. We also include the densities for the overall Canadian population, which are calculated using the 2001 Canadian Census master file. ${ }^{33}$ The densities of the cognitive skill requirements of the

unwilling to move unless they face similar economic opportunities in the host country. For an extensive review of the economic literature on incentives for migration, see Bodvarsson and Van den Berg (2009).

31 We exclude other economic class immigrants, such as the spouse of the principal applicant, in these calculations.

32 Likewise, currently half the available points in the Express Entry system can be obtained for pre-arranged employment.

33 We calculate the Canadian population densities using data for both males and females. These densities therefore reflect the occupational distribution that we use as a weight in constructing our skill measures from the relevant O*NET variables (see section 3.3). 
TABLE 2

Difference between mean Canadian and source country occupational skill requirements for skilled worker principal applicants, non-economic immigrants and immigrants with pre-arranged employment

\begin{tabular}{|c|c|c|c|c|c|c|}
\hline & \multicolumn{2}{|c|}{$\begin{array}{c}\text { Skilled worker } \\
\text { principal applicant }\end{array}$} & \multicolumn{2}{|c|}{$\begin{array}{l}\text { Non-economic } \\
\text { immigrants }\end{array}$} & \multicolumn{2}{|c|}{$\begin{array}{c}\text { Pre-arranged } \\
\text { employment }\end{array}$} \\
\hline & $\begin{array}{l}\text { LSIC } \\
6 \text { months }\end{array}$ & $\begin{array}{c}\text { LSIC } \\
4 \text { years }\end{array}$ & $\begin{array}{l}\text { LSIC } \\
6 \text { months }\end{array}$ & $\begin{array}{c}\text { LSIC } \\
4 \text { years }\end{array}$ & $\begin{array}{l}\text { LSIC } \\
6 \text { months }\end{array}$ & $\begin{array}{c}\text { LSIC } \\
4 \text { years }\end{array}$ \\
\hline Interpersonal & $\begin{array}{c}-1.03^{* *} \\
(0.04)\end{array}$ & $\begin{array}{c}-0.68^{* *} \\
(0.03)\end{array}$ & $\begin{array}{l}-0.97^{* *} \\
(0.06)\end{array}$ & $\begin{array}{c}-0.77^{* *} \\
(0.05)\end{array}$ & $\begin{array}{c}-0.24^{* *} \\
(0.07)\end{array}$ & $\begin{array}{c}-0.26^{* *} \\
0.07)\end{array}$ \\
\hline Analytical & $\begin{array}{c}-1.26^{* *} \\
(0.05)\end{array}$ & $\begin{array}{c}-0.84^{* *} \\
(0.04)\end{array}$ & $\begin{array}{c}-0.90^{* *} \\
(0.06)\end{array}$ & $\begin{array}{c}-0.73^{* *} \\
(0.05)\end{array}$ & $\begin{array}{c}-0.20^{* *} \\
(0.08)\end{array}$ & $\begin{array}{c}-0.29^{* *} \\
(0.08)\end{array}$ \\
\hline Fine motor & $\begin{array}{l}0.58^{* *} \\
(0.03)\end{array}$ & $\begin{array}{l}0.47^{* *} \\
(0.03)\end{array}$ & $\begin{array}{l}0.34^{* *} \\
(0.06)\end{array}$ & $\begin{array}{l}0.36^{* *} \\
(0.05)\end{array}$ & $\begin{array}{l}0.00 \\
(0.06)\end{array}$ & $\begin{array}{c}0.10 \\
(0.08)\end{array}$ \\
\hline Visual & $\begin{array}{l}0.26^{* *} \\
(0.03)\end{array}$ & $\begin{array}{l}0.25^{* *} \\
(0.03)\end{array}$ & $\begin{array}{c}-0.09 \\
(0.07)\end{array}$ & $\begin{array}{c}0.06 \\
(0.06)\end{array}$ & $\begin{array}{c}-0.11 \\
(0.07)\end{array}$ & $\begin{array}{c}-0.02 \\
(0.08)\end{array}$ \\
\hline Physical strength & $\begin{array}{l}0.77^{* *} \\
(0.04)\end{array}$ & $\begin{array}{l}0.56^{* *} \\
(0.03)\end{array}$ & $\begin{array}{l}0.43^{* *} \\
(0.06)\end{array}$ & $\begin{array}{l}0.47^{* *} \\
(0.05)\end{array}$ & $\begin{array}{c}0.03 \\
(0.07)\end{array}$ & $\begin{array}{c}0.10 \\
(0.08)\end{array}$ \\
\hline Observations & 938 & 1,137 & 334 & 538 & 125 & 113 \\
\hline
\end{tabular}

NOTES: Standard errors in parentheses. Level of significance between Canadian and source country occupational skill requirement denoted by ${ }^{* *} p<0.01,{ }^{*} p<0.05,{ }^{+} p<0.1$. LSIC sample based on workers with positive earnings and non-missing source and host country occupation codes. Sample restricted to males aged 24 to 59 at the time of cycle 1.

source country occupations lie above those for the domestic born population at higher values of the cognitive skill measure. Strength and other manual skill requirements for immigrants' occupations in Canada, in contrast, have distributions that are more concentrated at lower values of skill requirements than those of the domestic born population. Comparing the distributions of immigrant occupational skill requirements in Canada to those of the Canadian population suggests that immigrants converge to the Canadian population in terms of cognitive skill requirements within four years after arrival. Note, however, that immigrants are different in terms of their observable human capital endowments. For example, a much higher percentage of immigrants have obtained a university degree relative to the domestic-born population. ${ }^{34}$ In terms of occupational skill requirements, the densities in figure 3 suggest that immigrants' pre-migration occupations were more cognitive skill intensive than the occupations of the domestic-born population. In that case,

34 The percentage of the domestic born university degree holders (with positive earnings) in the 2001 Census is $20 \%$ compared to $64.5 \%$ in the sample of immigrants in the LSIC (with positive earnings in cycle 3). Similarly, in the 2001 Census data, $60.3 \%$ of male immigrants with positive earnings who immigrated in 2000 have a university degree. 


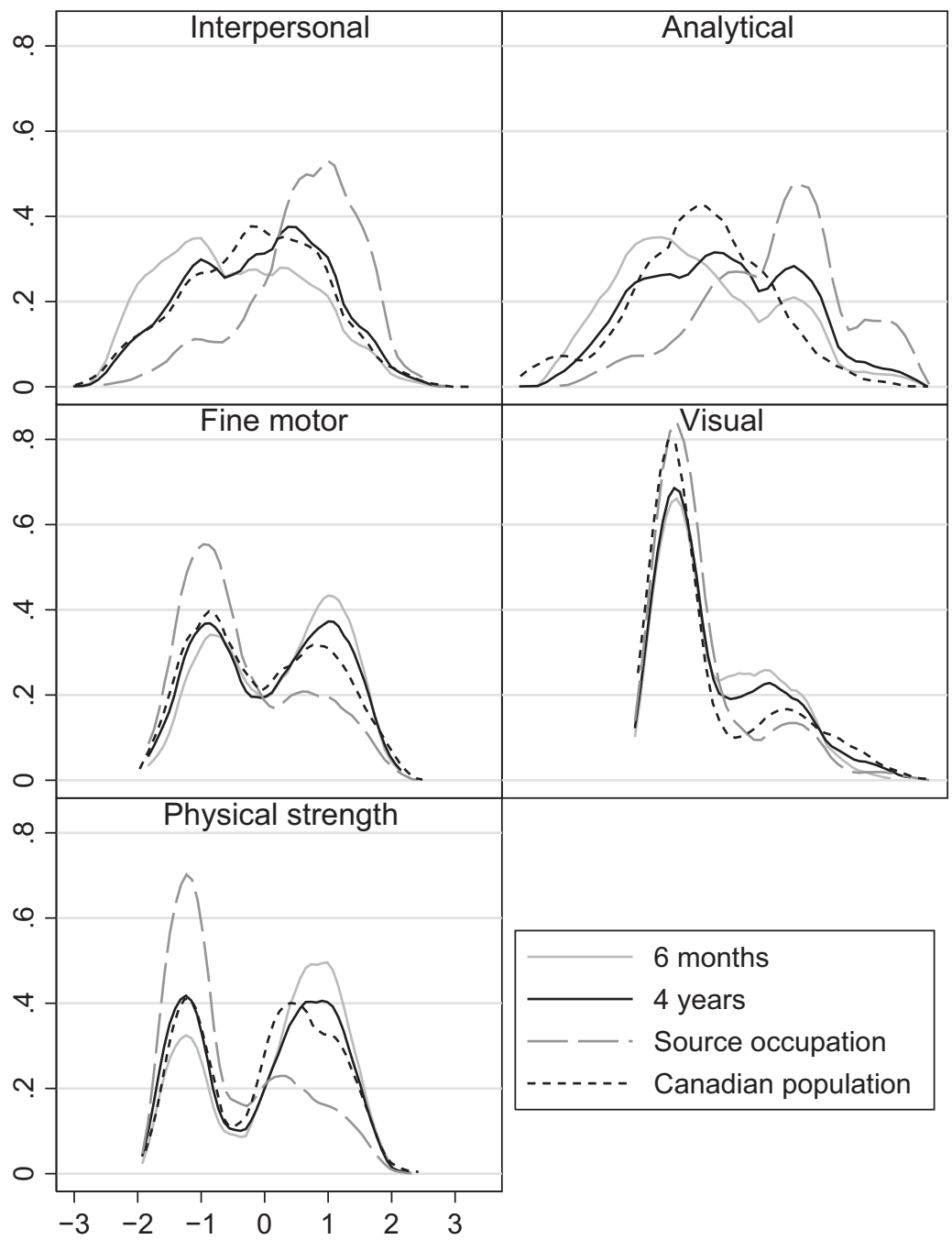

FIGURE 3 Density estimates for the skill requirements of source country occupations and Canadian occupations of immigrants, along with the density estimate for the overall Canadian population

convergence merely to the Canadian population distributions may still imply underutilization of immigrants' cognitive skills. ${ }^{35}$

35 We use occupation information reported at the time of landing, yet immigrants may have experienced changes in occupational skill content in the source country had they not emigrated resulting from, for example, skill accumulation/depreciation. The correct counterfactual would be the skills in the source country at the time of interview in Canada had the immigrant not emigrated. Consequently, our estimates may misstate convergence. 


\subsection{The role of language fluency}

In the context of the skills-based model, a lack of fluency in the dominant language impedes the transferability of occupational human capital to the domestic labour market. The sample statistics and density estimates discussed above suggest that immigrants are arriving in Canada with high cognitive to manual skill ratios. The conjectured asymmetric effect of language proficiency on the transferability of different types of skills should result in large cognitive skill gaps and smaller manual skill gaps. This is consistent with the skill requirement gaps reported in columns 1 and 4 of table 1, except that the model does not predict positive manual skill gaps. Rather, the negative gaps for manual skills should be smaller than those for cognitive skills. The positive manual skill gaps in the data could arise because of a negative correlation between the cognitive and manual skill requirements of occupations for labour market demand side reasons, which are not modelled in section 2. If occupations that require low levels of Canada usable cognitive skills tend to involve excessive manual tasks, then the detrimental effect of language fluency on cognitive skill transferability could lead to the observed positive gaps in the requirements of manual skills. The covariance matrix of the skill requirements, which is available from the authors upon request, affirms the presence of strong negative correlations between cognitive and manual skills.

To investigate whether the documented gaps between the imputed skill requirements of source country occupations and those of Canadian occupations are related to dominant language fluency, we present mean skill requirements for subsamples based on self-assessed language fluency in English or French in table 3. All language groups experience declines in occupational cognitive skill requirements. However, the gaps are much smaller for immigrants with better language ability. Furthermore, there is very little change between the skill gaps six months and four years after arrival among native English/French speakers, which is not the case for the other language groups. We also re-estimate the densities in figure 3 for the sample of immigrants whose mother tongue is the dominant language of the local labour market. These densities (see figure 4) reveal that the mismatch is less severe relative to the full sample. This descriptive evidence aligns with the view that the transferability of skills relies critically on dominant language proficiency, particularly for cognitive skills. As previously discussed, however, one should be concerned about potential measurement error affecting the results that apply the skills derived from O*NET to all countries. To address this issue, we report the average skill gaps for the Census sample of OECD immigrants by language group in table 4 and for the LSIC sample of immigrants from a single non-OECD source country by language group in table 5 .

The OECD sample provides a useful benchmark to the extent that OECD countries exhibit less variation along human capital dimensions. The results are again consistent with the language interpretation; differences in skill requirements are on average larger for OECD immigrants who are less fluent 


\section{TABLE 3}

Difference between mean Canadian and source country occupational skill requirements, by language group

\begin{tabular}{|c|c|c|c|c|c|c|}
\hline \multirow[b]{2}{*}{ Language group } & \multicolumn{3}{|c|}{$\begin{array}{c}\text { LSIC } \\
6 \text { months }\end{array}$} & \multicolumn{3}{|c|}{$\begin{array}{c}\text { LSIC } \\
4 \text { years }\end{array}$} \\
\hline & $\begin{array}{l}\text { Poorly/ } \\
\text { fairly well/ } \\
\text { well }\end{array}$ & $\begin{array}{l}\text { Very } \\
\text { well }\end{array}$ & $\begin{array}{l}\text { Mother } \\
\text { tongue }\end{array}$ & $\begin{array}{l}\text { Poorly/ } \\
\text { fairly well/ } \\
\text { well }\end{array}$ & $\begin{array}{l}\text { Very } \\
\text { well }\end{array}$ & $\begin{array}{l}\text { Mother } \\
\text { tongue }\end{array}$ \\
\hline Interpersonal & $\begin{array}{c}-1.29^{* *} \\
(0.04)\end{array}$ & $\begin{array}{c}-0.94^{* *} \\
(0.04)\end{array}$ & $\begin{array}{c}-0.34^{* *} \\
(0.07)\end{array}$ & $\begin{array}{c}-0.87^{* *} \\
(0.03)\end{array}$ & $\begin{array}{c}-0.62^{* *} \\
(0.04)\end{array}$ & $\begin{array}{c}-0.31^{* *} \\
(0.06)\end{array}$ \\
\hline Analytical & $\begin{array}{c}-1.47^{* *} \\
(0.05)\end{array}$ & $\begin{array}{c}-1.08^{* *} \\
(0.05)\end{array}$ & $\begin{array}{c}-0.42^{* *} \\
(0.08)\end{array}$ & $\begin{array}{c}-1.01^{* *} \\
(0.04)\end{array}$ & $\begin{array}{c}-0.69^{* *} \\
(0.05)\end{array}$ & $\begin{array}{c}-0.39^{* *} \\
(0.07)\end{array}$ \\
\hline Fine motor & $\begin{array}{l}0.61^{* *} \\
(0.04)\end{array}$ & $\begin{array}{c}0.54^{* *} \\
(0.04)\end{array}$ & $\begin{array}{c}0.12^{+} \\
(0.07)\end{array}$ & $\begin{array}{l}0.52^{* *} \\
(0.03)\end{array}$ & $\begin{array}{l}0.43^{* *} \\
(0.04)\end{array}$ & $\begin{array}{l}0.17^{* *} \\
(0.06)\end{array}$ \\
\hline Visual & $\begin{array}{l}0.19^{* *} \\
(0.04)\end{array}$ & $\begin{array}{l}0.23^{* *} \\
(0.04)\end{array}$ & $\begin{array}{c}0.04 \\
(0.07)\end{array}$ & $\begin{array}{l}0.24^{* *} \\
(0.03)\end{array}$ & $\begin{array}{l}0.22^{* *} \\
(0.03)\end{array}$ & $\begin{array}{c}0.01 \\
(0.06)\end{array}$ \\
\hline Physical strength & $\begin{array}{l}0.85^{* *} \\
(0.04)\end{array}$ & $\begin{array}{c}0.68^{* *} \\
(0.04)\end{array}$ & $\begin{array}{c}0.22^{* *} \\
(0.07)\end{array}$ & $\begin{array}{c}0.64^{* *} \\
(0.04)\end{array}$ & $\begin{array}{c}0.50^{* *} \\
(0.04)\end{array}$ & $\begin{array}{l}0.27^{* *} \\
(0.07)\end{array}$ \\
\hline Observations & 714 & 603 & 159 & 989 & 758 & 180 \\
\hline
\end{tabular}

NOTES: Standard errors in parentheses. Level of significance between Canadian and source country occupational skill requirement denoted by ${ }^{* *} p<0.01,{ }^{*} p<0.05,{ }^{+} p<0.1$. LSIC sample based on workers with positive earnings and non-missing source and host country occupation codes. Sample restricted to males aged 24 to 59 at the time of cycle 1.

in the dominant language. The data suggest that OECD immigrants that do not speak English/French at home (column 1, bottom of table 4) work in host country jobs that require interpersonal and analytical skills that are on average 0.60 and 0.77 standard deviations below those of their imputed source country occupations. In terms of fine motor skills and physical strength, the predicted skill requirements of OECD immigrants' source country occupations tend to be less than their Canadian occupations for this language group (skills gaps of 0.44 and 0.60 standard deviations respectively). For OECD immigrants that speak the dominant language at home regularly (column 2) or most often (column 3), these skill gaps are smaller in magnitude but still statistically significant. In contrast, skill gaps almost disappear entirely for OECD immigrants whose mother tongue is the local language (column 4). These are interesting findings that align well with our language fluency based interpretation of skill transferability.

We next examine the occupational skill requirements of immigrants from a single source country, but with varying reported levels of language proficiency. We select the sample of immigrants from China, since it is the source country in the LSIC with enough respondents to produce separate estimates by language group. By focusing on a single country, the source country and Canadian occupational skill requirement comparisons cannot be driven by differences in the true occupational skill requirements across source countries. We need only to assume that a skill requirement of each occupation 


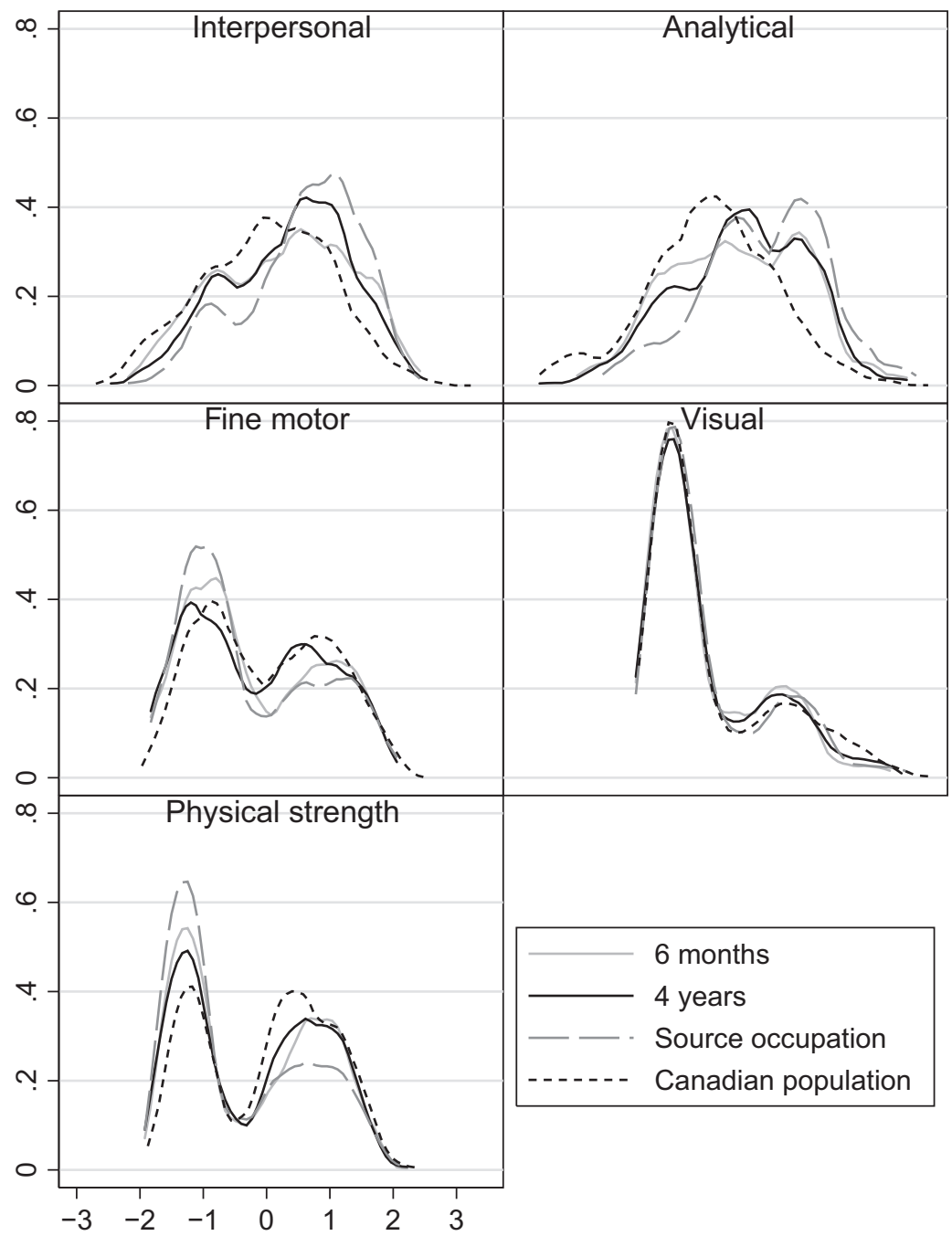

FIGURE 4 The density estimates for the skill requirements of source country occupations and Canadian occupations of immigrants who are native English/French speakers, along with the density estimate for the overall Canadian population

in China is a positive monotonic transformation of the skill requirement of the corresponding occupation derived from the information contained in O*NET. For example, engineers and taxi drivers may require different skills in China than in Canada, but engineers require more analytical skills than taxi drivers in both countries.

In table 5, we present the differences between source country (China) and host country (Canada) occupational skill requirements of Chinese 


\section{TABLE 4}

Difference between mean Canadian and predicted source country and occupational skill requirements, by language group

\begin{tabular}{|c|c|c|c|c|c|}
\hline \multirow[b]{2}{*}{ Language group } & \multicolumn{5}{|c|}{ Census } \\
\hline & $\begin{array}{l}\text { Does not } \\
\text { speak local } \\
\text { language }\end{array}$ & $\begin{array}{l}\text { Does not } \\
\text { speak } \\
\text { at home }\end{array}$ & $\begin{array}{l}\text { Speaks } \\
\text { at home } \\
\text { regularly }\end{array}$ & $\begin{array}{l}\text { Speaks } \\
\text { at home } \\
\text { most often }\end{array}$ & $\begin{array}{l}\text { Mother } \\
\text { tongue }\end{array}$ \\
\hline Interpersonal & $\begin{array}{c}-0.80^{* *} \\
(0.06)\end{array}$ & $\begin{array}{c}-0.72^{* *} \\
(0.01)\end{array}$ & $\begin{array}{c}-0.71^{* *} \\
(0.01)\end{array}$ & $\begin{array}{c}-0.60^{* *} \\
(0.02)\end{array}$ & $\begin{array}{c}-0.33^{* *} \\
(0.02)\end{array}$ \\
\hline Analytical & $\begin{array}{c}-0.92^{* *} \\
(0.07)\end{array}$ & $\begin{array}{c}-0.75^{* *} \\
(0.02)\end{array}$ & $\begin{array}{c}-0.73^{* *} \\
(0.02)\end{array}$ & $\begin{array}{c}-0.64^{* *} \\
(0.02)\end{array}$ & $\begin{array}{c}-0.37^{* *} \\
(0.02)\end{array}$ \\
\hline Fine motor & $\begin{array}{l}0.46^{* *} \\
(0.05)\end{array}$ & $\begin{array}{l}0.51^{* *} \\
(0.01)\end{array}$ & $\begin{array}{l}0.48^{* *} \\
(0.01)\end{array}$ & $\begin{array}{l}0.37^{* *} \\
(0.02)\end{array}$ & $\begin{array}{c}0.17^{* *} \\
(0.02)\end{array}$ \\
\hline Visual & $\begin{array}{c}-0.09^{+} \\
(0.05)\end{array}$ & $\begin{array}{l}0.13^{* *} \\
(0.01)\end{array}$ & $\begin{array}{l}0.11^{* *} \\
(0.01)\end{array}$ & $\begin{array}{l}0.06^{* *} \\
(0.02)\end{array}$ & $\begin{array}{c}-0.03 \\
(0.02)\end{array}$ \\
\hline Physical strength & $\begin{array}{l}0.74^{* *} \\
(0.06)\end{array}$ & $\begin{array}{l}0.53^{* *} \\
(0.01)\end{array}$ & $\begin{array}{l}0.51^{* *} \\
(0.02)\end{array}$ & $\begin{array}{l}0.41^{* *} \\
(0.02)\end{array}$ & $\begin{array}{l}0.22^{* *} \\
(0.02)\end{array}$ \\
\hline \multirow[t]{2}{*}{ Observations } & 300 & 4,710 & 3,910 & 2,950 & 2,070 \\
\hline & \multicolumn{5}{|c|}{ Census OECD } \\
\hline Language group & $\begin{array}{l}\text { Does not speak local } \\
\text { language or does not } \\
\text { speak at home }\end{array}$ & $\begin{array}{l}\text { Speaks } \\
\text { at home } \\
\text { regularly }\end{array}$ & $\begin{array}{l}\text { Speaks } \\
\text { at home } \\
\text { most often }\end{array}$ & $\begin{array}{l}\text { Mother } \\
\text { tongue }\end{array}$ & \\
\hline Interpersonal & $\begin{array}{c}-0.60^{* *} \\
(0.04)\end{array}$ & $\begin{array}{c}-0.38^{* *} \\
(0.05)\end{array}$ & $\begin{array}{c}-0.28^{* *} \\
(0.05)\end{array}$ & $\begin{array}{c}-0.01 \\
(0.03)\end{array}$ & \\
\hline Analytical & $\begin{array}{c}-0.77^{* *} \\
(0.05)\end{array}$ & $\begin{array}{c}-0.52^{* *} \\
(0.05)\end{array}$ & $\begin{array}{c}-0.28^{* *} \\
(0.05)\end{array}$ & $\begin{array}{c}-0.05^{+} \\
(0.03)\end{array}$ & \\
\hline Fine motor & $\begin{array}{l}0.44^{* *} \\
(0.04)\end{array}$ & $\begin{array}{l}0.24^{* *} \\
(0.05)\end{array}$ & $\begin{array}{l}0.17^{* *} \\
(0.05)\end{array}$ & $\begin{array}{c}-0.08^{* *} \\
(0.03)\end{array}$ & \\
\hline Visual & $\begin{array}{c}-0.09^{* *} \\
(0.03)\end{array}$ & $\begin{array}{c}-0.09^{+} \\
(0.05)\end{array}$ & $\begin{array}{c}0.02 \\
(0.04)\end{array}$ & $\begin{array}{c}-0.09^{* *} \\
(0.03)\end{array}$ & \\
\hline Physical strength & $\begin{array}{l}0.60^{* *} \\
(0.04)\end{array}$ & $\begin{array}{l}0.37^{* *} \\
(0.05)\end{array}$ & $\begin{array}{l}0.23^{* *} \\
(0.05)\end{array}$ & $\begin{array}{c}-0.04 \\
(0.03)\end{array}$ & \\
\hline Observations & 610 & 345 & 315 & 825 & \\
\hline
\end{tabular}

NOTES: Standard errors in parentheses. Level of significance between Canadian and source country occupational skill requirement denoted by ${ }^{* *} p<0.01,{ }^{*} p<0.05,{ }^{+} p<0.1$. Census sample based on immigrants with positive earnings in 2006. Sample restricted to males aged 30 to 65 , but that immigrated between the ages of 25 and 59. Census OECD sample further restricted to exclude immigrants from non-OECD countries. Predicted source country occupational skill requirements (as per equation (13)) used as source country measures in calculating differences.

immigrants by language group. ${ }^{36}$ The results are the same qualitatively as the main language-related results presented in tables 3 (LSIC full sample) and 4 (Census full sample and OECD subsample). Better language proficiency is associated with smaller China-Canada differences in pre- and post-migration

36 Table 5 contains three language groups defined slightly differently than in table 3 because there are no Chinese immigrants reporting English or French as their mother tongue. 
TABLE 5

Difference between mean Canadian and source country occupational skill requirements, by language group, Chinese immigrants

\begin{tabular}{|c|c|c|c|c|c|c|}
\hline \multirow[b]{2}{*}{ Language group } & \multicolumn{3}{|c|}{$\begin{array}{c}\text { LSIC } \\
6 \text { months }\end{array}$} & \multicolumn{3}{|c|}{$\begin{array}{c}\text { LSIC } \\
4 \text { years }\end{array}$} \\
\hline & $\begin{array}{c}\text { Poor/ } \\
\text { fairly well }\end{array}$ & Well & $\begin{array}{l}\text { Very } \\
\text { well }\end{array}$ & $\begin{array}{l}\text { Poor/ } \\
\text { fairly well }\end{array}$ & Well & $\begin{array}{l}\text { Very } \\
\text { well }\end{array}$ \\
\hline Interpersonal & $\begin{array}{c}-1.86^{* *} \\
(0.14)\end{array}$ & $\begin{array}{c}-1.42^{* *} \\
(0.12)\end{array}$ & $\begin{array}{c}-1.07^{* *} \\
(0.20)\end{array}$ & $\begin{array}{c}-1.27^{* *} \\
(0.11)\end{array}$ & $\begin{array}{c}-0.83^{* *} \\
(0.09)\end{array}$ & $\begin{array}{c}-0.65^{* *} \\
(0.14)\end{array}$ \\
\hline Analytical & $\begin{array}{c}-2.11^{* *} \\
(0.17)\end{array}$ & $\begin{array}{c}-1.73^{* *} \\
(0.15)\end{array}$ & $\begin{array}{c}-1.10^{* *} \\
(0.26)\end{array}$ & $\begin{array}{c}-1.46^{* *} \\
(0.13)\end{array}$ & $\begin{array}{c}-0.99^{* *} \\
(0.12)\end{array}$ & $\begin{array}{r}-0.53^{*} \\
(0.22)\end{array}$ \\
\hline Fine motor & $\begin{array}{l}1.04^{* *} \\
(0.12)\end{array}$ & $\begin{array}{l}0.81^{* *} \\
(0.10)\end{array}$ & $\begin{array}{l}0.79 * * \\
(0.16)\end{array}$ & $\begin{array}{l}0.90^{* *} \\
(0.11)\end{array}$ & $\begin{array}{l}0.60^{* *} \\
(0.09)\end{array}$ & $\begin{array}{l}0.52^{* *} \\
(0.15)\end{array}$ \\
\hline Visual & $\begin{array}{l}0.49^{* *} \\
(0.10)\end{array}$ & $\begin{array}{l}0.36^{* *} \\
(0.08)\end{array}$ & $\begin{array}{l}0.47^{* *} \\
(0.13)\end{array}$ & $\begin{array}{l}0.49^{* *} \\
(0.10)\end{array}$ & $\begin{array}{l}0.30^{* *} \\
(0.07)\end{array}$ & $\begin{array}{l}0.31^{* *} \\
(0.12)\end{array}$ \\
\hline Physical strength & $\begin{array}{l}1.32^{* *} \\
(0.11)\end{array}$ & $\begin{array}{l}1.11^{* *} \\
(0.11)\end{array}$ & $\begin{array}{l}0.94^{* *} \\
(0.18)\end{array}$ & $\begin{array}{l}1.03^{* *} \\
(0.11)\end{array}$ & $\begin{array}{l}0.67^{* *} \\
(0.09)\end{array}$ & $\begin{array}{l}0.62^{* *} \\
(0.16)\end{array}$ \\
\hline Observations & 84 & 99 & 38 & 111 & 142 & 55 \\
\hline
\end{tabular}

NOTES: Standard errors in parentheses. Level of significance between Canadian and source country occupational skill requirement denoted by ${ }^{* *} p<0.01,{ }^{*} p<0.05,{ }^{+} p<0.1$. LSIC sample based on workers with positive earnings and non-missing source and host country occupation codes. Sample restricted to males aged 24 to 59 at the time of cycle 1 .

occupational skill requirements. More specifically, both the drop in cognitive skill requirements after migration and the increase in manual skill requirements are smaller with better host country language fluency. These qualitative similarities suggest that our results relating differences in skill requirements to language proficiency are not solely driven by cross country differences in occupational skill requirements. ${ }^{37,38}$

Motivated by the similarities between the qualitative patterns reported in tables 3, 4 and 5, we further explore the robustness of the relationship between skill gaps and language fluency with regression analysis. We estimate the following equation separately for each of the five skill requirements:

$$
\Delta s_{i}=\beta_{0}+\beta_{1} s_{i}^{\mathrm{SRC}}+\beta_{2} A g e_{i}+\beta_{3} l_{i}+\theta_{i}^{j}+\epsilon_{i},
$$

37 In addition, Chinese immigrants reporting higher English language proficiency did not tend to work in occupations in China that required higher cognitive skills than immigrants reporting lower levels of language proficiency (source country occupational skill requirements not shown, but available from the authors upon request). This suggests that our language-related results are not solely due to a positive correlation between language proficiency and the occupational human capital of the immigrants.

38 There of course remains the possibility that language ability is somehow correlated with other important unobserved factors, such as work ethic or pre-migration preparedness. 
where $A g e_{i}$ is age in years, $l_{i}$ is a set of language ability dummies (corresponding to the same language categories reported in tables 3 and 4) and $\theta_{i}^{j}$ is a vector of source country dummies. We include a set of source country dummies because language ability at the country level may be correlated with the quality of source country human capital. For instance, English/French language fluency could be a proxy for source country variation in the quality of education or credential recognition. ${ }^{39}$ For the LSIC estimates of $\Delta s_{i}=$ $s_{i}^{\mathrm{CDN}}-s_{i}^{\mathrm{SRC}}, s_{i}^{\mathrm{CDN}}$ is the imputed skill requirement of the Canadian job and $s_{i}^{\mathrm{SRC}}$ is the imputed skill requirement of the source country job. For the Census estimates, $\Delta s_{i}$ is similarly defined except that we use the predicted skill (as per equation (13)) as a measure of $s_{i}^{\mathrm{SRC}}$.

These results are reported in tables 6 and 7 . We first present the LSIC estimates for six months and four years after arrival in columns 1 and 2, respectively. In all specifications, the differences in skill gaps across language groups are similar to the simple means presented in table 3. Given that the sample size of the LSIC is too small for meaningful analysis with the OECD subsample, we again supplement our analysis with the Census. Column 3 presents the estimates for the full 2000-2001 Census immigrant arrival cohort, while column 4 presents the OECD subsample of this group. Again, even after controlling for source country, the estimates are very similar to those presented in table 4.

To the extent that dominant language proficiency improves with time in the host country, we expect skill gaps to diminish with time since arrival. The smaller skill requirement gaps reported in columns 2 and 5 (four years after arrival) relative to columns 1 and 4 (six months after arrival) in table 1 align well with the theory. Moreover, the change over time is more dramatic for cognitive skills than for manual skills, which is consistent with the assertion in the model that the mobility of certain skills (namely, cognitive skills) is more sensitive to language fluency. The finding that convergence is more pronounced among immigrants less fluent in the dominant language in table 3 is further suggestive of the importance of language proficiency for cross-border skill mobility provided that dominant language fluency improves with time since migration. We next take a closer look at the evidence of convergence in skill requirements among immigrants at low initial dominant language fluency levels using responses to the language proficiency questions in different cycles of the LSIC. This allows us to directly study the link between the decline in skill gaps and reported improvement in language ability. Table 8 reports results from regressing the change in skill requirement between cycle 1 (six months after arrival) and cycle 3 (four years after arrival) on an indicator

39 The estimates are generally very similar if we control for 18 regions of origin instead of the individual source country or if we control for the difference between source country GDP per capita and Canada's GDP per capita. 
TABLE 6

Cognitive skill gap regressions with country dummies

\begin{tabular}{|c|c|c|c|c|c|}
\hline & $\begin{array}{c}\text { LSIC } \\
6 \text { months }\end{array}$ & $\begin{array}{l}\text { LSIC } \\
4 \text { years }\end{array}$ & & $\begin{array}{l}\text { Census } \\
\text { full sample }\end{array}$ & $\begin{array}{l}\text { Census } \\
\text { OECD }\end{array}$ \\
\hline \multirow[t]{2}{*}{ Language group } & \multicolumn{2}{|c|}{ Interpersonal } & Language group & \multicolumn{2}{|c|}{ Interpersonal } \\
\hline & & & $\begin{array}{l}\text { Does not speak } \\
\text { at home }\end{array}$ & $\begin{array}{c}0.130^{*} \\
(0.0591)\end{array}$ & $\begin{array}{c}0.031 \\
(0.0539)\end{array}$ \\
\hline Well $^{1}$ & $\begin{array}{r}0.289^{* *} \\
(0.0844)\end{array}$ & $\begin{array}{r}0.350^{* *} \\
(0.0592)\end{array}$ & $\begin{array}{l}\text { Speaks at home } \\
\text { regularly }^{1}\end{array}$ & $\begin{array}{r}0.173^{* *} \\
(0.0493)\end{array}$ & $\begin{array}{c}0.197^{*} \\
(0.0802)\end{array}$ \\
\hline Very well ${ }^{1}$ & $\begin{array}{r}0.672^{* *} \\
(0.0832)\end{array}$ & $\begin{array}{r}0.635^{* *} \\
(0.0600)\end{array}$ & $\begin{array}{l}\text { Speaks at home } \\
\text { most often }{ }^{1}\end{array}$ & $\begin{array}{r}0.278^{* *} \\
(0.0539)\end{array}$ & $\begin{array}{l}0.220^{*} \\
(0.0960)\end{array}$ \\
\hline Mother tongue $^{1}$ & $\begin{array}{r}0.911^{* *} \\
(0.2644)\end{array}$ & $\begin{array}{r}0.645^{* *} \\
(0.1860)\end{array}$ & Mother tongue $^{1}$ & $\begin{array}{r}0.315^{* *} \\
(0.0762)\end{array}$ & $\begin{array}{r}0.294^{* *} \\
(0.0895)\end{array}$ \\
\hline \multirow[t]{2}{*}{ Language group } & \multicolumn{2}{|c|}{ Analytical } & Language group & \multicolumn{2}{|c|}{ Analytical } \\
\hline & & & $\begin{array}{c}\text { Does not speak } \\
\text { at home }\end{array}$ & $\begin{array}{r}0.215^{* *} \\
(0.0652)\end{array}$ & $\begin{array}{c}0.163^{+} \\
(0.0867)\end{array}$ \\
\hline Well $^{2}$ & $\begin{array}{c}0.229^{*} \\
(0.0946)\end{array}$ & $\begin{array}{r}0.409^{* *} \\
(0.0657)\end{array}$ & $\begin{array}{l}\text { Speaks at home } \\
\text { regularly }^{2}\end{array}$ & $\begin{array}{r}0.263^{* *} \\
(0.0559)\end{array}$ & $\begin{array}{r}0.278^{* *} \\
(0.0999)\end{array}$ \\
\hline Very well $^{2}$ & $\begin{array}{r}0.613^{* *} \\
(0.0877)\end{array}$ & $\begin{array}{r}0.734^{* *} \\
(0.0704)\end{array}$ & $\begin{array}{l}\text { Speaks at home } \\
\text { most often }{ }^{2}\end{array}$ & $\begin{array}{r}0.362^{* *} \\
(0.0466)\end{array}$ & $\begin{array}{r}0.356^{* *} \\
(0.0906)\end{array}$ \\
\hline Mother tongue ${ }^{2}$ & $\begin{array}{r}0.667^{* *} \\
(0.2026)\end{array}$ & $\begin{array}{r}0.696^{* *} \\
(0.1910)\end{array}$ & Mother tongue ${ }^{2}$ & $\begin{array}{r}0.403^{* *} \\
(0.0706)\end{array}$ & $\begin{array}{r}0.359^{* *} \\
(0.0975)\end{array}$ \\
\hline Observations & 1,476 & 1,927 & Observations & 13,940 & 2,090 \\
\hline No. of clusters & 105 & 115 & No. of clusters & 161 & 29 \\
\hline${ }^{1} P$-value & 0.000 & 0.000 & ${ }^{1} P$-value & 0.000 & 0.027 \\
\hline${ }^{2} P$-value & 0.000 & 0.000 & ${ }^{2} P$-value & 0.000 & 0.004 \\
\hline
\end{tabular}

NOTES: All regressions include a constant and controls for age, source country skill requirements (predicted values for the Census estimates) and country of birth. The default language group is "Poorly/fairly well" for the first 2 columns and "Does not speak the local language" for columns 3 and 4 . Robust standard errors in parentheses clustered on source country. Level of significance denoted by ${ }^{* *} p<0.01,{ }^{*} p<0.05,{ }^{+} p<0.1$. P-values in bottom rows are for $F$-tests of the joint significance of the language group dummies.

LSIC sample based on workers with positive earnings and non-missing source and host country occupation codes. Sample restricted to males aged 24 to 59 at the time of cycle 1. The dependent variable is the difference between Canadian and source country occupational skill requirements.

Census sample based on immigrants with positive earnings in 2006. Sample restricted to males aged 30 to 65 , but that immigrated between the ages of 25 and 59 . Census OECD sample further restricted to exclude immigrants from non-OECD countries. The dependent variable is the difference between Canadian and predicted (as per equation (13)) source country occupational skill requirements.

variable for improved language ability over the same time period. We control for both source country and cycle 1 skill requirements. We include the former to account for the potentially transferable skill content of source country occupations and the latter to focus exclusively on the transfer of additional skills between cycles 1 and 3. The sample is restricted to those who speak English/French "poorly," "fairly well" or "well" in cycle 1, since there is no scope for language improvement among immigrants whose mother tongue is the local language or who report speaking English/French "very well." We 


\section{TABLE 7}

Manual skill gap regressions with country dummies

\begin{tabular}{|c|c|c|c|c|c|}
\hline \multirow[b]{2}{*}{ Language group } & $\begin{array}{c}\text { LSIC } \\
6 \text { months }\end{array}$ & $\begin{array}{l}\text { LSIC } \\
4 \text { years }\end{array}$ & & $\begin{array}{l}\text { Census } \\
\text { full sample }\end{array}$ & $\begin{array}{l}\text { Census } \\
\text { OECD }\end{array}$ \\
\hline & \multicolumn{2}{|c|}{ Fine motor } & Language group & \multicolumn{2}{|c|}{ Fine motor } \\
\hline & & & $\begin{array}{c}\text { Does not speak } \\
\text { at home }\end{array}$ & $\begin{array}{l}-0.002 \\
(0.0274)\end{array}$ & $\begin{array}{c}0.074 \\
(0.0543)\end{array}$ \\
\hline $\mathrm{Well}^{3}$ & $\begin{array}{r}-0.200^{* *} \\
(0.0659)\end{array}$ & $\begin{array}{r}-0.216^{* *} \\
(0.0605)\end{array}$ & $\begin{array}{c}\text { Speaks at home } \\
\text { regularly }\end{array}$ & $\begin{array}{l}-0.042 \\
(0.0379)\end{array}$ & $\begin{array}{c}-0.078 \\
(0.0789)\end{array}$ \\
\hline Very well ${ }^{3}$ & $\begin{array}{r}-0.358^{* *} \\
(0.0639)\end{array}$ & $\begin{array}{r}-0.368^{* *} \\
(0.0708)\end{array}$ & $\begin{array}{c}\text { Speaks at home } \\
\text { most often }\end{array}$ & $\begin{array}{l}-0.145^{*} \\
(0.0621)\end{array}$ & $\begin{array}{c}-0.049^{*} \\
(0.0980)\end{array}$ \\
\hline Mother tongue $^{3}$ & $\begin{array}{r}-0.761^{* *} \\
(0.2523)\end{array}$ & $\begin{array}{l}-0.425 \\
(0.2746)\end{array}$ & Mother tongue $^{3}$ & $\begin{array}{l}-0.162 \\
(0.1087)\end{array}$ & $\begin{array}{r}-0.111 \\
(0.0985)\end{array}$ \\
\hline \multirow[t]{2}{*}{ Language group } & \multicolumn{2}{|c|}{ Visual } & Language group & \multicolumn{2}{|c|}{ Visual } \\
\hline & & & $\begin{array}{c}\text { Does not speak } \\
\text { at home }\end{array}$ & $\begin{array}{r}0.151^{* *} \\
(0.0399)\end{array}$ & $\begin{array}{r}0.323^{* *} \\
(0.0716)\end{array}$ \\
\hline Well $^{4}$ & $\begin{array}{r}-0.158^{* *} \\
(0.0424)\end{array}$ & $\begin{array}{c}-0.168^{*} \\
(0.0787)\end{array}$ & $\begin{array}{l}\text { Speaks at home } \\
\text { regularly }\end{array}$ & $\begin{array}{l}0.110^{*} \\
(0.0511)\end{array}$ & $\begin{array}{r}0.236^{* *} \\
(0.0764)\end{array}$ \\
\hline Very well ${ }^{4}$ & $\begin{array}{r}-0.215^{* *} \\
(0.0804)\end{array}$ & $\begin{array}{r}-0.285^{* *} \\
(0.0915)\end{array}$ & $\begin{array}{c}\text { Speaks at home } \\
\text { most often }\end{array}$ & $\begin{array}{l}0.050 \\
(0.0583)\end{array}$ & $\begin{array}{c}0.258^{*} \\
(0.1022)\end{array}$ \\
\hline Mother tongue ${ }^{4}$ & $\begin{array}{c}-0.387^{*} \\
(0.1778)\end{array}$ & $\begin{array}{l}-0.322 \\
(0.2547)\end{array}$ & Mother tongue ${ }^{4}$ & $\begin{array}{l}0.032 \\
(0.0871)\end{array}$ & $\begin{array}{c}0.234^{*} \\
(0.1088) \\
\end{array}$ \\
\hline \multirow[t]{2}{*}{ Language group } & \multicolumn{2}{|c|}{ Physical strength } & Language group & \multicolumn{2}{|c|}{ Physical strength } \\
\hline & & & $\begin{array}{c}\text { Does not speak } \\
\text { at home }\end{array}$ & $\begin{array}{r}-0.210^{* *} \\
(0.0389)\end{array}$ & $\begin{array}{l}-0.040 \\
(0.0777)\end{array}$ \\
\hline Well $^{5}$ & $\begin{array}{l}-0.189^{*} \\
(0.0781)\end{array}$ & $\begin{array}{r}-0.248^{* *} \\
(0.0690)\end{array}$ & $\begin{array}{l}\text { Speaks at home } \\
\text { regularly }\end{array}$ & $\begin{array}{r}-0.244^{* *} \\
(0.0437)\end{array}$ & $\begin{array}{r}-0.160^{+} \\
(0.0861)\end{array}$ \\
\hline Very well ${ }^{5}$ & $\begin{array}{r}-0.404^{* *} \\
(0.0853)\end{array}$ & $\begin{array}{r}-0.441^{* *} \\
(0.0697)\end{array}$ & $\begin{array}{l}\text { Speaks at home } \\
\text { most often }\end{array}$ & $\begin{array}{r}-0.324^{* *} \\
(0.0589)\end{array}$ & $\begin{array}{l}-0.171^{*} \\
(0.0819)\end{array}$ \\
\hline Mother tongue $^{5}$ & $\begin{array}{r}-0.661^{* *} \\
(0.2292)\end{array}$ & $\begin{array}{r}-0.419^{+} \\
(0.2454)\end{array}$ & Mother tongue $^{5}$ & $\begin{array}{r}-0.328^{* *} \\
(0.0989)\end{array}$ & $\begin{array}{r}-0.284^{* *} \\
(0.0922)\end{array}$ \\
\hline $\begin{array}{l}\text { Observations } \\
\text { No. of clusters }\end{array}$ & $\begin{array}{r}1,476 \\
105\end{array}$ & 1,927 & Observations & $\begin{array}{r}13,940 \\
161\end{array}$ & $\begin{array}{r}2,090 \\
29\end{array}$ \\
\hline No. of clusters & 105 & 115 & No. of clusters & 161 & 29 \\
\hline${ }^{3} P$-value & 0.000 & 0.000 & ${ }^{3} P$-value & 0.004 & 0.069 \\
\hline${ }^{4} P$-value & 0.004 & 0.000 & ${ }^{4} P$-value & 0.000 & 0.002 \\
\hline${ }^{5} P$-value & 0.000 & 0.000 & ${ }^{5} P$-value & 0.000 & 0.028 \\
\hline
\end{tabular}

NOTE: See notes for table 6 .

also include dummies for cycle 1 language ability in case the latitude for improvement depends on initial ability. For the specifications in columns 2 and 3, we include the GDP difference (i.e., the difference between source country GDP per capita and Canada's GDP per capita) and country dummies, respectively. In column 4, we also control for the overcoming of other obstacles to labour market integration. These additional controls are constructed from a set of LSIC questions prompting respondents to attribute difficulties encountered in the Canadian labour market to unrecognized credentials or 
TABLE 8

Canadian skill improvement (6 months to 4 years) regressions

\begin{tabular}{|c|c|c|c|c|}
\hline & (1) & $(2)$ & (3) & (4) \\
\hline & \multicolumn{4}{|c|}{ Interpersonal } \\
\hline $\begin{array}{l}\text { Language improved } \\
\text { ( } 6 \text { months to } 4 \text { years) }\end{array}$ & $\begin{array}{l}0.156^{*} \\
(0.0698)\end{array}$ & $\begin{array}{c}0.157^{* *} \\
(0.0573) \\
\text { Anal }\end{array}$ & $\begin{array}{c}0.192^{*} \\
(0.0744)\end{array}$ & $\begin{array}{c}0.192^{*} \\
(0.0748)\end{array}$ \\
\hline $\begin{array}{l}\text { Language improved } \\
\text { (6 months to } 4 \text { years) }\end{array}$ & $\begin{array}{l}0.125 \\
(0.0782)\end{array}$ & $\begin{array}{c}0.123 \\
(0.0770) \\
\text { Fine }\end{array}$ & $\begin{array}{c}0.183^{+} \\
(0.1005)\end{array}$ & $\begin{array}{c}0.183^{+} \\
(0.0996)\end{array}$ \\
\hline $\begin{array}{l}\text { Language improved } \\
\text { ( } 6 \text { months to } 4 \text { years) }\end{array}$ & $\begin{array}{l}-0.146^{*} \\
(0.0683)\end{array}$ & $\begin{array}{c}-0.156^{* *} \\
(0.0567)\end{array}$ & $\begin{array}{l}-0.156^{*} \\
(0.0647)\end{array}$ & $\begin{array}{c}-0.156^{*} \\
(0.0603)\end{array}$ \\
\hline $\begin{array}{l}\text { Language improved } \\
\text { (6 months to } 4 \text { years) }\end{array}$ & $\begin{array}{l}-0.015 \\
(0.0623)\end{array}$ & $\begin{array}{c}-0.023 \\
(0.0616) \\
\text { Physical }\end{array}$ & $\begin{array}{l}-0.015 \\
(0.0625) \\
\text { ngth }\end{array}$ & $\begin{array}{l}-0.016 \\
(0.0566)\end{array}$ \\
\hline $\begin{array}{l}\text { Language improved } \\
\text { (6 months to } 4 \text { years) }\end{array}$ & $\begin{array}{l}-0.093 \\
(0.0692)\end{array}$ & $\begin{array}{l}-0.093^{+} \\
(0.0505)\end{array}$ & $\begin{array}{l}-0.120^{*} \\
(0.0509)\end{array}$ & $\begin{array}{c}-0.115^{*} \\
(0.0535)\end{array}$ \\
\hline Canadian skills (6 months) & YES & YES & YES & YES \\
\hline GDP difference & NO & YES & NO & NO \\
\hline Country dummies & $\mathrm{NO}$ & $\mathrm{NO}$ & YES & YES \\
\hline Improvement in other factors & NO & NO & NO & YES \\
\hline Observations & 726 & 710 & 726 & 726 \\
\hline
\end{tabular}

NOTES: All regressions include source country skill level and language ability controls at the time of cycle 1. "Improvement in other factors" includes four indicator variables for labour market difficulties reported in cycle 1 that are no longer identified as problems in cycle 3 . The four variables are related to unrecognized credentials or foreign work experience, insufficient knowledge of the local labour market, underdeveloped social networks and discrimination. Level of significance denoted by ${ }^{* *} p<0.01,{ }^{*} p<0.05,{ }^{+} p<0.1$.

LSIC sample based on workers with positive earnings and non-missing source and host country occupation codes in both cycles 1 and 3. Sample restricted to males aged 24 to 59 at the time of cycle 1 that did not speak the local language "very well" at the time of cycle 1 or indicate it as their "mother tongue."

foreign work experience, insufficient knowledge of the local labour market, underdeveloped social networks or discrimination. We identify improvement along these dimensions whenever a problem was reported in cycle 1 but not cycle 3. We describe these variables in greater detail in section 4.3.

The estimates reported in table 8 support the hypothesized role of language in skill transferability insofar as language improvement is associated with increases in cognitive skill requirements and decreases in manual skill requirements. In other words, the decline in occupational skill gaps is more dramatic among immigrants that become more proficient in the dominant language. For specifications that include country dummies (columns 3 and 4), these results are statistically significant for all skills except visual. Moreover, the estimates of interest remain largely unaltered with the inclusion of additional variables. The estimates for cognitive skills imply that immigrants reporting improvement in language ability tend to also switch occupations in such a way that interpersonal and analytical skill gaps decline by additional amounts 
equivalent to at least one half and one third the subsample average cognitive skill gap reductions from cycle 1 to cycle $3 .{ }^{40}$

\subsection{Other contributing factors}

Occupational skill gaps could be driven by language fluency as well as a variety of other factors. In this section, we further explore some of the labour market related questions in the LSIC to determine whether other labour market frictions besides dominant language fluency influence the cross-border transferability of occupational skills. The Employment section of the LSIC questionnaire includes a series of questions of the form: "What problems or difficulties have you had in finding a job in Canada:...?" We construct dummy variables for an affirmative response to these labour market obstacles in at least one of the LSIC interviews. In particular, we generate a variable for unaccepted foreign credentials and unrecognized foreign work experience if an immigrant answers "yes" to the above question with either "qualifications from outside Canada not accepted" or "job experience from outside Canada not accepted." Similarly, we generate a variable for incomplete knowledge of the local labour market based on the questions with "do not know how to find a job" or "do not know the city or town." To account for underdeveloped social networks among immigrants, we use affirming responses to any of the questions with "don't know enough people who are working," "no connections in the job market" or "no family or friends who can help." Finally, a dummy variable for labour market discrimination is constructed from the "discrimination" question.

The results are reported in table 9 . We estimate nearly identical regressions to those reported in the columns labelled "LSIC 4 years" of tables 6 and 7 . The dependent variables (gaps in cognitive and manual skill requirements in cycle 3) are the same and so are the explanatory variables, except that we also include the dummy variables described above. We learn two things from this set results. First, only the network variable contributes to the mismatch of occupational skill requirements, but only in terms of manual skills. Second, even when conditioning on these other labour market frictions, the coefficients on the language group dummies remain statistically significant and comparable to those in the relevant columns of tables 6 and 7 . This further supports our view that dominant language proficiency is essential to the understanding of the cross-border mobility of immigrants' occupational human capital.

40 These mean reductions in interpersonal and analytical skill requirements are 0.33 and 0.36 for the subsample of LSIC immigrants that did not speak the local language "very well" at the time of cycle 1 or that indicated it as their "mother tongue." 
TABLE 9

Skill gap regressions with other factors

\begin{tabular}{lccccc}
\hline & $\begin{array}{c}(1) \\
\text { Interpersonal }\end{array}$ & $\begin{array}{c}(2) \\
\text { Analytical }\end{array}$ & $\begin{array}{c}(3) \\
\text { Fine } \\
\text { motor }\end{array}$ & $\begin{array}{c}(4) \\
\text { Visual }\end{array}$ & $\begin{array}{c}(5) \\
\text { Physical } \\
\text { strength }\end{array}$ \\
\hline Insufficient knowledge & -0.0762 & -0.0534 & 0.00311 & 0.00243 & 0.0244 \\
of the local labour market & $(0.0884)$ & $(0.0954)$ & $(0.0678)$ & $(0.0547)$ & $(0.0726)$ \\
Underdeveloped & -0.0404 & -0.0293 & $0.117^{* *}$ & $0.0943^{* *}$ & $0.0786^{+}$ \\
social networks & $(0.0431)$ & $(0.0523)$ & $(0.0367)$ & $(0.0330)$ & $(0.0462)$ \\
Unrecognized credentials or & -0.0169 & -0.0591 & 0.0431 & 0.0303 & 0.0654 \\
foreign work experience & $(0.0598)$ & $(0.0655)$ & $(0.0564)$ & $(0.0569)$ & $(0.0630)$ \\
Experienced discrimination & -0.0482 & -0.0865 & -0.0184 & -0.0542 & -0.0387 \\
Language group & $(0.0713)$ & $(0.0689)$ & $(0.0674)$ & $(0.0499)$ & $(0.0723)$ \\
Well & $0.387^{* *}$ & $0.426^{* *}$ & $-0.278^{* *}$ & $-0.225^{* *}$ & $-0.331^{* *}$ \\
Very well & $(0.0663)$ & $(0.0621)$ & $(0.0591)$ & $(0.0482)$ & $(0.0556)$ \\
Mother tongue & $0.713^{* *}$ & $0.792^{* *}$ & $-0.510^{* *}$ & $-0.374^{* *}$ & $-0.562^{* *}$ \\
& $(0.0815)$ & $(0.0749)$ & $(0.0668)$ & $(0.0608)$ & $(0.0767)$ \\
\hline Country dummies & $0.623^{* *}$ & $0.643^{* *}$ & $-0.470^{+}$ & $-0.370^{+}$ & $-0.449^{+}$ \\
\hline Observations & $(0.176)$ & $(0.179)$ & $(0.270)$ & $(0.220)$ & $(0.239)$ \\
\hline
\end{tabular}

NOTES: All regressions include a constant and controls for age and source country skill requirements. Default category: age is 40 years, country of birth is China, language group is "poorly/fairly well." Robust standard errors in parentheses clustered on source country. Level of significance denoted by ${ }^{* *} p<0.01,{ }^{*} p<0.05,{ }^{+} p<0.1$.

LSIC cycle 3 sample based on workers with positive earnings and non-missing source and host country occupation codes. Sample restricted to males aged 24 to 59 at the time of cycle 1 .

\section{Conclusion}

In this paper, we analyze the skill requirements of immigrants' source country occupations and study the transferability of these skills to the Canadian economy. Canada, like many immigrant-receiving countries, favours highly educated workers, and there is an expectation that immigrants will therefore contribute to high-skill sectors. Using a skills-based model of human capital with cross-border skill conversion, we argue that limited language proficiency hinders the complete transfer of occupational human capital from the source country to the host country. Some immigrants end up in occupations that do not align well with their source country skills, which generates discrepancies between the skills required on the job and the ones accrued prior to immigrating.

Our empirical analysis supports the view that Canada is successful in admitting workers that have experience in occupations that require high cognitive skills, and hence tend to require low manual skills. Upon entering the Canadian labour market, however, the evidence suggests that they either seek or settle for occupations that require not only lower cognitive skills but also higher manual skills. Consistent with the theory, imputed skill gaps are 
larger among immigrants with poorer language ability. Immigrants fluent in English/French exhibit minimal skill discrepancies after coming to Canada, and this remains unchanged even after four years in Canada. On the other hand, the large skill gaps of immigrants with limited English/French proficiency improve substantially with time spent in the Canadian labour market, perhaps in part because of language acquisition. Even skilled worker principal applicants have very similar outcomes to non-screened immigrants despite having been directly chosen based on the human capital that, in principle, should help them readily attain economic and occupational success in Canada.

Without similar O*NET datasets devised separately for every country, our empirical analysis must rely to some extent on the assumption that cross-country differences in the skill requirements of occupations are not too great. In our attempts to minimize reliance on this assumption, we demonstrate that similar qualitative results hold for subsets of immigrants where the measurement problems are arguably less severe (i.e., immigrants from OECD countries) or less problematic (i.e., immigrants from the same source country). Our quantitative results can be broadly interpreted as a skillsbased description of the differences between immigrants' source country and Canadian occupational titles. In terms of measuring the gap between true country-specific occupational skill requirements, however, our analysis should be viewed more as exploratory than conclusive. Future work in this area may further the study of human capital mobility among workers emigrating from only one country or a small number of countries. It could then become feasible to assess the relevance of the $\mathrm{O}^{*} \mathrm{NET}$-derived skill content by comparing them to source country specific human capital measures obtained using other human capital surveys.

\section{References}

Adserà, A., and A. Ferrer (2014) "The myth of immigrant women as secondary workers: Evidence from Canada," The American Economic Review: Papers $\&$ Proceedings 104(5), 360-64

(2015) "The effect of linguistic proximity on the occupational assimilation of immigrant men in Canada," working paper no. 1503, University of Waterloo Department of Economics

— (2016) "Occupational skills and labour market progression of married immigrant women in Canada," Labour Economics 39(C), 88-98

Aydede, Y., and A. Dar (2016) "The cost of immigrants, occupational mismatch and the effectiveness of postarrival policies in Canada," IZA Journal of Migration 5(1), 9 pp.

Aydemir, A., and M. Skuterud (2005) "Explaining the deteriorating entry earnings of Canada's immigrant cohorts: 1966-2000," Canadian Journal of Economics $38(2), 641-72$

Bacolod, M. P., and B. S. Blum (2010) "Two sides of the same coin: U.S. 'residual' inequality and the gender gap," Journal of Human Resources 45(1), 197-242 
Beach, C. (2006) "Employment-based permanent immigration: Examining the value of a skills-based point system". Statement before the U.S. Senate Committee on Health, Education, Labor, and Pensions

Beach, C., A. Green, and C. Worswick (2007) "Impacts of the point system and immigration policy levers on skill characteristics of Canadian immigrants," Research in Labor Economics 27, 349-401

Belot, M. V., and T. J. Hatton (2012) "Immigrant selection in the OECD," The Scandinavian Journal of Economics 114(4), 1105-28

Berman, E., K. Lang, and E. Siniver (2003) "Language-skill complementarity: Returns to immigrant language acquisition," Labour Economics 10(3), 265-90

Bodvarsson, Ö. B., and H. Van den Berg (2009) "Why people immigrate: The evidence." In The Economics of Immigration, pp. 59-77. Springer

Bowlus, A. J., M. Miyairi, and C. Robinson (2016) "Immigrant job search assimilation in Canada," Canadian Journal of Economics 49(1), 5-51

Chapin, A. (2012, December 19) "Canada immigration: Foreign skilled workers struggle to find jobs in their professions," The Huffington Post. Available at huffingtonpost.ca/2012/12/19/canada-immigration-foreign-skilledworkers_n_2293003.html

Chiswick, B. R., and N. DebBurman (2004) "Educational attainment: Analysis by immigrant generation," Economics of Education Review 23(4), 361-79

Chiswick, B. R., and P. W. Miller (1995) "The endogeneity between language and earnings: International analyses," Journal of Labor Economics 13(2), 246-88 (2003) "The complementarity of language and other human capital: Immigrant earnings in Canada," Economics of Education Review 22(5), 469-80

- (2008) "Why is the payoff to schooling smaller for immigrants?," Labour Economics 15(6), 1317-40

— (2009) "Educational mismatch: Are high-skilled immigrants really working at high-skilled jobs and the price they pay if they aren't?," IZA discussion paper no. 4280

- (2012) "Negative and positive assimilation, skill transferability, and linguistic distance," Journal of Human Capital 6(1), 35-55

- (2013) "The impact of surplus skills on earnings: Extending the over-education model to language proficiency," Economics of Education Review $36,263-75$

Cohen-Goldner, S., and Z. Eckstein (2010) "Estimating the return to training and occupational experience: The case of female immigrants," Journal of Econometrics 156(1), 86-105

Coulombe, S., G. Grenier, and S. Nadeau (2014) "Human capital quality and the immigrant wage gap," IZA Journal of Migration 3(1), 1-22

Dean, J. (2010) "The economic integration of Canadian immigrants," PhD thesis, McGill University

Dechief, D., and P. Oreopoulos (2012) "Why do some employers prefer to interview Matthew, but not Samir? New evidence from Toronto, Montreal, and Vancouver," SSRN working paper

Dharssi, A. (2016, September 19) "Skilled immigrants wasting their talents in Canada," Calgary Herald. Available at calgaryherald.com/storyline/ skilled-immigrants-wasting-their-talents-in-canada

Ferrer, A., D. Green, and C. Riddell (2006) "The effect of literacy on immigrant earnings," Journal of Human Resources 41(2), 380-410 
Ferrer, A., and W. C. Riddell (2008) "Education, credentials, and immigrant earnings," Canadian Journal of Economics 41(1), 186-216

Gathmann, C., and U. Schönberg (2010) "How general is human capital? A task-based approach," Journal of Labor Economics 28(1), 1-49

Green, C., P. Kler, and G. Leeves (2007) "Immigrant overeducation: Evidence from recent arrivals to Australia," Economics of Education Review 26(4), 420-32

Green, D. A. (1999) "Immigrant occupational attainment: Assimilation and mobility over time," Journal of Labor Economics 17(1), 49-79

Green, D. A., and C. Worswick (2012) "Immigrant earnings profiles in the presence of human capital investment: Measuring cohort and macro effects," Labour Economics 19(2), 241-59

Ingram, B. F., and G. R. Neumann (2006) "The returns to skill," Labour Economics 13(1), 35-59

Kambourov, G., and I. Manovskii (2009) "Occupational specificity of human capital," International Economic Review 50(1), 63-115

Kaushal, N., Y. Lu, N. Denier, J. S.-H. Wang, and S. J. Trejo (2016) "Immigrant employment and earnings growth in Canada and the USA: Evidence from longitudinal data," Journal of Population Economics 29(4), 1249-77

Lazear, E. P. (2009) "Firm-specific human capital: A skill-weights approach," Journal of Political Economy 117(5), 914-40

Li, Q., and A. Sweetman (2014) "The quality of immigrant source country educational outcomes: Do they matter in the receiving country?," Labour Economics 26, 81-93

Lindley, J. (2009) "The over-education of UK immigrants and minority ethnic groups: Evidence from the Labour Force Survey," Economics of Education Review 28(1), 80-89

Neal, D. (1995) "Industry-specific human capital: Evidence from displaced workers," Journal of Labor Economics 13(4), 653-77

Nielsen, C. P. (2011) "Immigrant over-education: Evidence from Denmark," Journal of Population Economics 24(2), 499-520

Oreopoulos, P. (2011) "Why do skilled immigrants struggle in the labor market? A field experiment with thirteen thousand resumes," American Economic Journal: Economic Policy 3(4), 148-71

Parent, D. (2000) "Industry-specific capital and the wage profile: Evidence from the National Longitudinal Survey of Youth and the Panel Study of Income Dynamics," Journal of Labor Economics 18(2), 306-23

Peri, G., and C. Sparber (2009) "Task specialization, immigration, and wages," American Economic Journal: Applied Economics 1(3), 135-69

Phelan, B. J. (2013) "Task mismatch and the reemployment of displaced workers," manuscript, DePaul University

Poletaev, M., and C. Robinson (2008) "Human capital specificity: Evidence form the Dictionary of Occupational Titles and Displaced Worker Surveys, 1984-2000," Journal of Labor Economics 26(3), 387-420

Robinson, C. (2018) "Occupational mobility, occupation distance and specific human capital," Journal of Human Resources 53(2), 513-551

Schaafsma, J., and A. Sweetman (2001) "Immigrant earnings: Age at immigration matters," Canadian Journal of Economics 34(4), 1066-99 
Schuetze, H., and J. Wood (2014) "Immigrant networks, occupational choice, and match quality," working paper, University of Victoria Department of Economics

Sharaf, M. F. (2013) "Job-education mismatch and its impact on the earnings of immigrants: Evidence from recent arrivals to Canada," ISRN Economics 2013, article 452358, 14 pages

Skuterud, M. (2011) "Language skills in the new economy and the deteriorating labour market performance of Canada's immigrant workers," HRSDC working paper

Skuterud, M., and M. Su (2012) "Immigrants and the dynamics of high-wage jobs: Evidence from the Canadian Labour Force Survey," Industrial and Labor Relations Review 65(2), 377-97

Sweetman, A., and C. Warman (2013) "Canada's immigration selection system and labour market outcomes," Canadian Public Policy 39 (Supp. 1), S141-S164

_ (2014) "Former temporary foreign workers and international students as sources of permanent immigration," Canadian Public Policy 40(4), 392-407

Torres, J. (2013) Essays on Immigrant Assimilation, PhD thesis, University of British Columbia

Warman, C. (2010) "The portability of human capital of male temporary foreign workers: You can bring it with you." In T. McDonald, E. Ruddick, A. Sweetman, and C. Worswick, eds., Canadian Immigration: Economic Evidence for a Dynamic Policy Environment, chapter 8. McGill-Queen's University Press

Warman, C., A. Sweetman, and G. Goldmann (2015) "The portability of new immigrants' human capital: Language, education and occupational skills," Canadian Public Policy 41 (Supp. 1), S64-S79

Warman, C., M. Webb, and C. Worswick (2019) "Immigrant category of admission and the earnings of adults and children: How far does the apple fall?," Journal of Population Economics 32(1), 53-112

Warman, C., and C. Worswick (2015) "Technological change, occupational tasks and declining immigrant outcomes: Implications for earnings and income inequality in Canada," Canadian Journal of Economics 48(2), 736-72

Yamaguchi, S. (2012) "Tasks and heterogeneous human capital," Journal of Labor Economics 30(1), 1-53

\section{Supporting information}

Additional supporting information can be found in the online version of this article. 